\title{
ALS-Based Detection of Past Human Activities in the Białowieża Forest-New Evidence of Unknown Remains of Past Agricultural Systems
}

\author{
Krzysztof Stereńczak ${ }^{1, *,+}{ }^{\mathbb{D}}$, Rafał Zapłata ${ }^{2,{ }^{\dagger}}$, Jarosław Wójcik ${ }^{1}$, Bartłomiej Kraszewski ${ }^{1}{ }^{\mathbb{D}}$, \\ Miłosz Mielcarek ${ }^{1}$, Krzysztof Mitelsztedt ${ }^{1}$, Małgorzata Białczak ${ }^{1}$ (D), Grzegorz Krok ${ }^{1}$ (D), \\ Lukasz Kuberski ${ }^{3}{ }^{(D)}$, Anna Markiewicz ${ }^{1}$, Aneta Modzelewska ${ }^{1}$ (D), Karolina Parkitna ${ }^{1}(\mathbb{D}$, \\ Żaneta Piasecka ${ }^{1}$, Kamil Pilch ${ }^{3}$, Karol Rzeczycki ${ }^{3}$, Rafał Sadkowski ${ }^{1}$, Martyna Wietecha ${ }^{1}$,

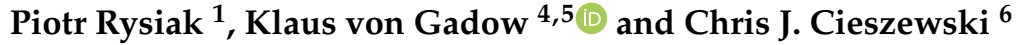 \\ 1 Department of Geomatics, Forest Research Institute, Sekocin Stary, 3 Braci Leśnej St., 05090 Raszyn, Poland; \\ jaroslaw.wojcik@3deling.com (J.W.); B.Kraszewski@ibles.waw.pl (B.K.); m.mielcarek@ibles.waw.pl (M.M.); \\ k.mitelsztedt@ibles.waw.pl (K.M.); m.bialczak@ibles.waw.pl (M.B.); g.krok@ibles.waw.pl (G.K.); \\ a.markiewicz@ibles.waw.pl (A.M.); a.modzelewska@ibles.waw.pl (A.M.); k.parkitna@ibles.waw.pl (K.P.); \\ z.piasecka@ibles.waw.pl (Ż.P.); rafal.sadkowski@triprog.com (R.S.); mwietecha@mggpaero.com (M.W.); \\ piotr.rysiak@laser-3d.pl (P.R.) \\ 2 School of Exact Sciences, Faculty of Mathematics and Natural Sciences, Cardinal Wyszyński University \\ in Warsaw, Wóycickiego Str.1/3, Building 21, 01938 Warszawa, Poland; r.zaplata@uksw.edu.pl \\ 3 Department of Natural Forests, Forest Research Institute, Białowieża, 6 Park Dyrekcyjny St., \\ 17230 Białowieża, Poland; l.kuberski@ibles.waw.pl (Ł.K.); k.pilch@ibles.waw.pl (K.P.); karolrz@op.pl (K.R.) \\ 4 Department of Forestry and Wood Science, University of Stellenbosch, Stellenbosch 7600, South Africa; \\ kgadow@gwdg.de \\ 5 Faculty of Forestry and Forest Ecology, University of Göttingen, 37073 Göttingen, Germany \\ 6 Warnell School of Forestry and Natural Resources, University of Georgia, 180 E Green Street, \\ Athens, GA 30602-2152, USA; biomat@warnell.uga.edu \\ * Correspondence: k.sterenczak@ibles.waw.pl; Tel.: +48-22-7150-325; Fax: +48-22-7200-397 \\ + These authors contributed equally to this work, and share the credit as first-author.
}

Received: 15 June 2020; Accepted: 10 August 2020; Published: 18 August 2020

\begin{abstract}
The Białowieża Forest (BF), a unique ecosystem of historical significance in central Europe, has a long history of assumed human settlement, with at least 200 known archaeological sites (until 2016). This study uncovers new evidence of the cultural heritage of this unique forest area using Airborne Laser Scanning (ALS) technology combined with traditional archaeological field assessment methods to verify the ALS data interpretations and to provide additional evidence about the function and origin of the newly detected archaeological sites. The results of this study include (1) a scientific approach for an improved identification of archaeological resources in forest areas; (2) new evidence about the history of the human use of the BF based on ALS data, covering the entire Polish part of the BF; and (3) an improved remote sensing infrastructure, supporting existing GIS (Geographic Information System) systems for the BF, a famous UNESCO Heritage site. Our study identified numerous locations with evidence of past human agricultural activities known in the literature as "field systems", "lynchets" and "Celtic fields". The initial identification included more than $300 \mathrm{~km}$ of possible field boundaries and plough headlands, many of which we have verified on the ground. Various past human activities creating those boundaries have existed since the (pre-) Roman Period up to the 13th century AD. The results of this study demonstrate that past human activities in the Polish part of the Białowieża Forest had been more prevalent than previously believed. As a practical result of the described activities, a geodatabase was created; this has practical applications for the system of monument protection in Poland, as well as for local communities and the BF's management and conservation. The more widely achieved results are in line with the implementation of the
\end{abstract}


concept of a cultural heritage inventory in forested and protected areas-the actions taken specify (built globally) the forms of protection and management of cultural and environmental goods.

Keywords: LiDAR; Białowieża Forest; anthropogenic remains; archaeology; UNESCO World Heritage Site; past field systems

\section{Introduction}

The Polish part of the Białowieża Forest (BF) has not yet been covered by large-area archaeological research using remote sensing data, and thus the institutions managing these areas did not have a systematic geodatabase of the cultural (historic) resources. Additionally, the monument protection system in Poland does not have a detailed geodatabase of all its archaeological monuments, which prompted specific actions to be taken as part of the initiative. Therefore, the construction of such a resource, among others as part of the undertakings of nationwide research institutions and teams, contributes to the construction of resources of public access, ultimately serving for the protection and management of cultural and environmental goods [1,2]. On a global scale, these types of activities contribute to the generation, collection and sharing of resources of UNESCO World Heritage sites, exploring the knowledge and providing data for the protection, promotion, monitoring and management of forest complexes, in line with the global trend in interdisciplinary activities [3-7].

The BF is a well-recognized European Forest, with large biodiversity and large areas under conservation. It was historically more open than it is today [8-13]. Fires were widespread in different periods in the past to the late 1700s, supporting claims of an open, pine-dominated forest with substantial human influence on the fire regimes [14]. Parts of BF are not remnants of ancient hardwood forests but are softwood stands, from which timber was floated to the Baltic ports connected to Europe's western industrial regions [15]. One of the most significant human impacts on the BF through the centuries was the maintenance of high populations of large herbivores for royal hunting. Large herbivores act as a negative filter by favouring the few species capable of withstanding the browsing pressure, thus reducing the native species biodiversity $[16,17]$. A variety of human activities have impacted the BF ecosystems throughout the past and still do today. All these human-related activities and natural processes result in a diverse and rich forest ecosystem that is unique on at least a European scale, is very valuable for biological and forest sciences, and is often visited by tourists from different parts of the world.

Until 2016, there had been 200 archaeological sites (approximately 800 single features, e.g., with their own landscape form/sculpture, including the so-called flat stands-we provide the approximate number due to incomplete documentation from previous studies) established on record within the Polish part of the Białowieża Forest (covering approximately 63,000 ha), most of which had not been investigated in detail apart from surface prospecting (Figure 1). Former archaeological research in the $\mathrm{BF}$ had been based on field observations that sought evidence provided by regular features, including local depressions or areas of raised elevation $[11,18,19]$. In areas with recorded local deformations, archaeological excavations and soil explorations were carried out where possible, and invasive investigations were launched into the anthropogenic origins of the site. Archaeological studies in the BF have revealed material evidence associated with human activities between a few thousand years ago and the modern era. The evidence includes cemeteries, relicts of settlements, proof of exploitation and production activities, military activities and historical buildings that were once present in this area [19]. Known archaeological sites in the Polish part of the BF have been recorded in the Polish Archaeological Records (Polish abbrev: AZP). Traces of human occupation and activity in the Białowieża Forest are known from the Stone Age—the late Paleolithic and Mesolithic-as well as from the Neolithic, the beginning of the Bronze Age (Neman and Trzciniec culture) and from the middle and late Bronze Era and the early Iron Age. Prehistoric times (especially the pre-Roman (approximately 
from the 5th century $\mathrm{BC}$ to the beginning of the 1st century $\mathrm{AD}$ ) and Roman influence (1st century AD to approximately the 4th century AD)) in this area represent the foundations of the culture of barium ceramics, evidenced by either the Przeworsk culture or the Wielbark culture. In ancient times, the BF was used in a variety of ways: for hay-mowing, bar-planting, foraging, fishing, firing tar and potash production, as well as for grazing of animals, hunting, gathering, mining, honey production, mushroom collecting and finally forest management of various kinds, including logging [20-22]. Most of the remnants of human activities are cemeteries or single graves [23], including cremation graves from the 8 th to the 9th century and inhumation graves from the 11th to the 12th century. From the 14th to the end of the 18th century, these areas were the royal hunting ground of the Jagiellonian dynasty [24]. As a result, even if the exploitation of BF has varied during the past few centuries, it is still one of the few lowland forests in Europe that has never been completely cleared of forest cover [25].
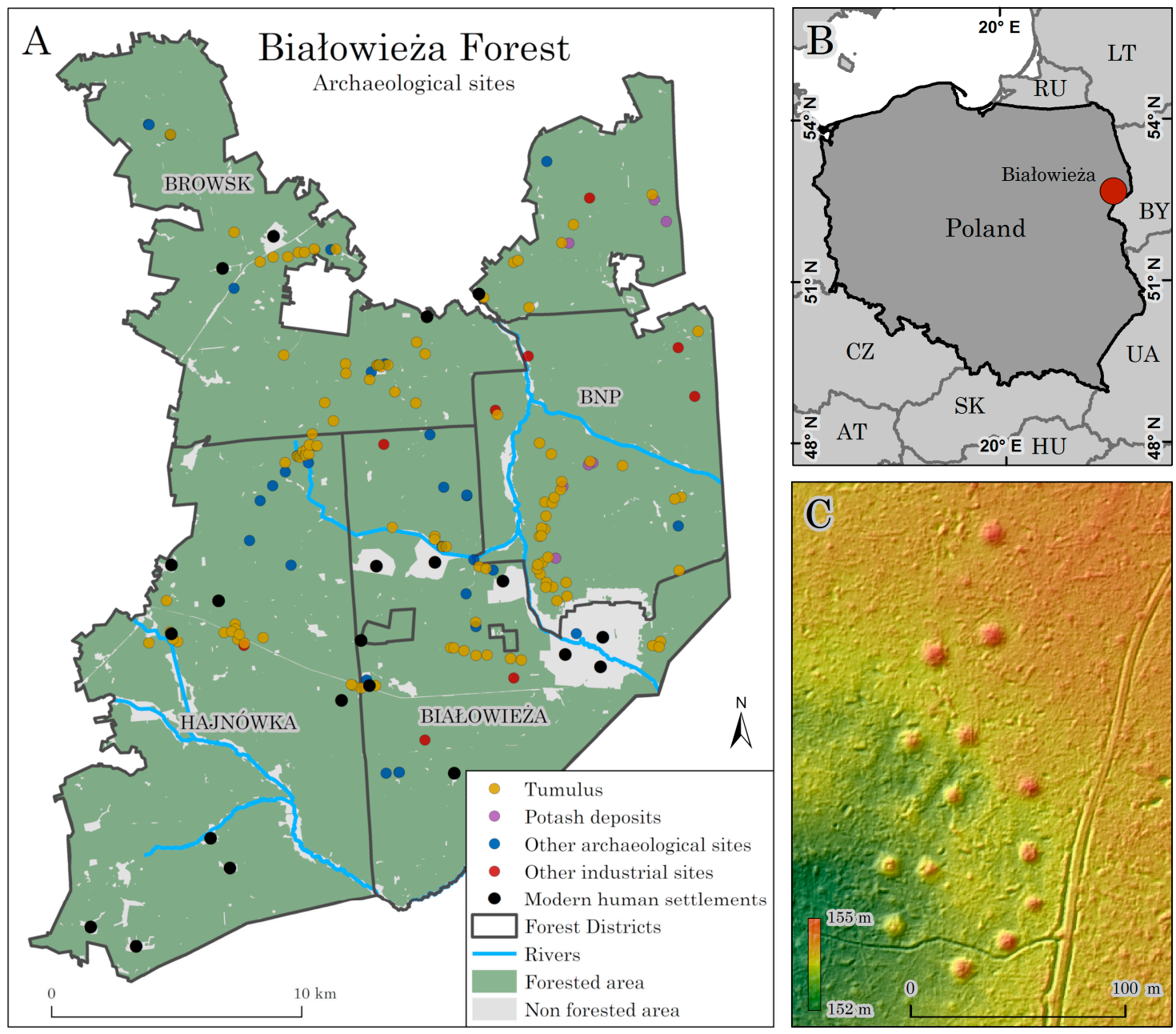

Figure 1. Location of the Białowieża Forest (B), archaeological sites identified before 2016 without use of Airborne Laser Scanning (ALS) data (A); example of an archaeological site identified as a barrow cemetery using ALS data (C). BNP—Białowieża National Park; Hajnówka, Białowieża and Browsk refer to the names of tree forest districts.

In the present study, the first of its kind on such a large scale in the BF, we collected data for the entire area by utilizing Light Detection and Ranging (LiDAR) technology mounted on an aircraft, also known as an Airborne Laser Scanning (ALS) system. In many recent archaeological projects, ALS was one of the leading methods [26-35]. In Europe, numerous archaeological projects use public ALS data [13], but their utility for archaeological purposes was often low (approximately $1 \mathrm{pts} / \mathrm{m}^{2}$ (points per square metre) or less), which means that other solutions, such as those dedicated to 
archaeology but also for natural research data acquisition, are necessary. It was no different in the Polish part of the Białowieża Forest, where two datasets were available. There are ALS data from the ISOK (Informatyczny System Osłony Kraju przed nadzwyczjnymi zagrożeniami-the computer system covers the country against extraordinary threats) project, covering almost the total area of Poland [36,37]. Only a part of the BF was available. However, in 2015, additional ALS data with higher density were obtained from the LIFE+ ForBioSensing project (www.forbiosensing.pl). The ForBioSensing ALS dataset was of much better quality and covers the whole BF, which is why it was used in the presented research.

ALS is an active remote sensing technology that gives users the ability of surveying large areas with high precision. ALS is capable of obtaining ground echoes even under forest canopies [38]. It was introduced to the archaeological community at the beginning of the 21st century and became an essential tool in the recognition of past human activity remains. There are many successful examples of using ALS data for inventories of archaeological objects under forest cover [7,39,40]. ALS data are exceptionally suitable for producing a Digital Terrain Model (DTM) of the ground under forest cover [41], and because of this functionality, ALS technology complements archaeological research in forested areas [42,43]. The DTM interpolated from ALS is extremely useful for identifying small-scale topographic anomalies [44]. Based on local changes, areas with probable anthropogenic origin are determined [45]. Visual DTM interpretation requires knowledge-based pattern recognition skills and the ability to identify and classify complex landforms based on experience and previous archaeological knowledge [46]. After detecting possible human-made features based on DTM interpretation, the field part of the research is carried out. In the field, previously marked areas are verified to confirm their actual origin and condition. Despite this complexity, it is possible to pinpoint potential human activity residues quite precisely, even in forest areas.

Based on the experience of other scientists worldwide, as well as the availability of ALS data, it was decided to verify whether such good results can also be achieved for the Polish part of the BF. The aim of this study was to detect the remains of past human activities and verify them in the field in the whole Polish part of the BF. The main output was recognized as a base for future deep studies of all human activity remains in order to verify the scale and degree of human influence on the BF. In this study, we are focusing on the identification of linear objects, as well as their detection and verification.

\section{Materials and Methods}

\subsection{Study Area}

The Białowieża Forest, a remnant of the Central European lowland forests that once occupied much of the central European lowland plains [47], covers approximately 150,000 ha with $42 \%$ of its area located in Poland (Figure 1). The Polish part of the BF (approximately 63,000 ha) comprises four distinct spatial entities: the Białowieża National Park (BNP), 10,517 ha; the Białowieża Forest District, 12,593 ha; the Browsk Forest District, 20,417 ha; and the Hajnówka Forest District, 19,654 ha. In 1979, the BNP area was included in the United Nations Organization for Education, Science and Culture (UNESCO) World Heritage List. The area of the UNESCO site was extended in 2014, and now covers an area of 141,885 ha, with a buffer zone of 166,708 ha [48], including the Polish and Belarusian parts of the BF.

\subsection{General Concept}

The concept of the inventory of archaeological heritage in the BF area is closely related to a broader undertaking - with the natural and cultural inventories of the State Forests National Forest Holding in Poland-which is an initiative to create digital resources like spatial data for other forest areas in Poland. Since 2016, these works have also been carried out in south-eastern Poland-mainly the 
area of the Regional Directorate of State Forests in Krosno that largely coincides with the area of the Podkarpackie Voivodeship.

Starting in 2016, the initiative to conduct extensive research in the study area towards the identification of archaeological (cultural) resources has been a large-scale interdisciplinary effort aimed at investigating various forms of evidence for past human activities; it includes the recognition, registration and protection of remains, as well as the public dissemination of information about these findings. The ongoing identification of archaeological heritage resources, including previously unknown objects and relics of field systems, is based on multi-element and multi-stage research procedures applied to the polish part of the Białowieża Forest. The procedures consist of (1a) acquisition and processing of archival and remote sensing data-mainly ALS-data and aerial images; (1b) analysis and interpretation of the data's correlations with existing research results from 2016 and with the Białowieża Forest's current parameters, such as contemporary topography and activities; (1c) analysis, interpretation and verification of the data about the identified objects during and after the field inspection of those objects; (2) multi-site field verifications of point probes and wells, and field surveys and excavations; and (3) specialized analyses, such as dating and analysis of the chemical soil composition, ecofacts and artefacts.

\subsection{Archival Data}

The analysis of archival resources included literature and other archival materials (e.g., aerial photos from World War II, archival maps) and documentation, including resources from the Provincial Office for the Protection of Monuments in Białystok, the Institute of Archaeology and Ethnology of the Polish Academy of Sciences and the Podlasie Museum in Białystok. In addition, archival resources acquired as part of the activities of the Forest Culture Centre in Gołuchów were analysed. This work involved the correlation of features of known archaeological objects (shape, size and location) with those of the newly recognized anthropogenic objects. Data related to land use, along with data on the occurrence and condition of potential archaeological resources, were also collected. The result of these activities is compiled into a database of 200 archaeological sites (Figure 1). Correlation with historical (archival) data indicates the probability of the destruction of some sites or single archaeological features. This can happen where, for forest renewal purposes, the top layer of soil is subjected to mechanical preparation for planting, or due to other activities or environmental processes.

\subsection{ALS Data}

Primary recognition of the potential archaeological objects was based on three critical elements associated with the ALS data: (i) the ALS data acquisition; (ii) data processing; and (iii) data interpretation. Raster data for the visual interpretation of potential archaeological objects in the Białowieża Forest were generated based on ALS data obtained in the leaf-off season between 25 November and 7 December 2015. The ALS data were collected with a full-waveform sensor Riegl LMS-Q680i scanner, with an average point density above $11 \mathrm{pts} / \mathrm{m}^{2}$ at a flying height of $500 \mathrm{~m}$ above ground. To cover the study area, 135 individual flight paths were flown with a $40 \%$ overlap. The horizontal accuracy was $0.20 \mathrm{~m}$ and the vertical accuracy was $0.15 \mathrm{~m}$. The point cloud was automatically classified into five classes using TerraSolid software based on the ASPRS 1.2 LAS format specification [49]:

- 2-Ground

- 3-Low vegetation

- 4-Average vegetation

- 5-High vegetation

- 6-Buildings and engineering buildings

The ALS ground point class data were used to produce a Digital Terrain Model (DTM) with a $0.5 \mathrm{~m}$ resolution. The vertical accuracy was verified using terrain points measured with the Global 
Positioning System-Real Time Kinematic (GPS-RTK) method. The DTM constituted the base for generating the derived products used in the inventory.

\subsection{DTM Processing}

Recognition of potential archaeological objects was based on different visualizations generated from the DTM [44,50]. These products were produced using the Relief Visualization Toolbox [42]. The following results of the ALS-based DTM processing were used in the interpretation (main visualizations):

- Slope Exposure Map [38] - a map presenting the azimuth of the ground (stocks) exposition.

- Aspect [41]—a map presenting the orientation of the slope.

- DTM relief hillshade [39] for eight azimuth positions: $0^{\circ}, 45^{\circ}, 90^{\circ}, 135^{\circ}, 180^{\circ}, 225^{\circ}, 270^{\circ}, 315^{\circ}$ and the horizon of $20^{\circ}$ (hillshade is a 3D representation of the surface, with the sun's relative position taken into account for shading the image).

- Local Relief Model [51]—it highlights small-scale surface features by removing large-scale landforms from the DTM.

- Sky-view factor [52] - a map presenting the proportion of the sky visible from a given point, allowing determination of the percentage of terrestrial visibility.

We used the open-source software QGIS (version 2.14) to standardize the inventory results of all the interpreters' work for viewing data and searching objects of interest. ESRI Shapefiles were created to store the final version of the interpretation. Uniform schematics made it easier to combine data from different interpreters, e.g., for the entire forest district. For each catalogued point of interest verified by an archaeologist, a part of a point cloud, raster image, terrain profile and 3D view were created to show the best representation of the terrain. We used the Profile Tool in the QGIS Toolbox to generate the elevation profile for the selected section. The basic inventory unit was the forest compartment. We used a convex polygon tool to calculate the area of the groups of linear objects, which were clearly detected and formed closed structures. Convex polygons create the smallest possible border around the marked object/clusters in our case. Afterwards, the area calculation was based on the borders around separate groups of detected linear objects.

In total, 2108 forest compartments were analysed in the whole research area, including 444 compartments in the Białowieża Forest District, 396 in Białowieża National Park, 598 in the Browsk Forest District and 670 in the Hajnówka Forest District. The average size of the forest compartment in the BF is approximately 3 ha. Military areas were excluded from the inventory.

\subsection{Primary Analysis and Interpretation}

The main focus of the analysis and interpretation of the ALS data was on the visual recognition of topographic differences, their locations, and their correspondence with other elements of the environment and with contemporary objects, as well as the correlation of their shapes, sizes and complexities with those of the objects they are found with in conjunction. The interpreters used many supplementary data to support their work, including

- road network features obtained from the Forest Digital Map;

- watercourse network features obtained from the Forest Digital Map;

- $\quad$ RGB and CIR orthophotos of the area.

The next stage of the inventory processing was to control the data accuracy and the integrity of the prepared shapefiles and processed attributes. The merged and validated file for the entire Forest District was passed to the archaeologist for verification. Figure 2 shows the workflow diagram for this process. Two approaches to analyse and interpret the ALS data were used in the research to identify cultural resources: (1) office works and (2) office-terrain works. The first one was based solely on 
the analysis of data in the form of "from the desk", and the second was based on the analysis and interpretation of data both as part of office and field work (beginning with terrain verification).

\begin{tabular}{|c|}
\hline ALS data acquisition \\
\hline ALS data preparation and preprocessing \\
\hline \\
\hline Inventory made by interpreters team \\
\hline Internal verification of primary interpretation results \\
\hline \\
\hline Data merging \\
\hline Preparation of ALS data and visual interpretation results for field verification \\
\hline Fiałowieża Forest Cultural Heritage GIS database/portal \\
\hline reation of ALS data interpretation \\
\hline \\
\hline \\
\hline
\end{tabular}

Figure 2. General workflow with ALS data acquisition, processing and interpretation, as well as the subsequent field-based verification.

\subsection{Preparations for Field Verification}

Figures 3 and 4 show the locations of potential archaeological objects (Section 3.1) indicated by the office team of interpreters in the Polish part of the Białowieża Forest. Based on layers with potential archaeological objects corrected by an archaeologist, cartographic materials and illustrations were prepared for the operational teams to find ALS-based identifications in the field. The review materials were created from the hillshade, local relief model, and other raster transformations. For proper interpretation of the data in the field, it was assumed that the scale of the visual materials should be 1:1000 for point objects, and 1:2500 for linear objects. Materials were saved in georeferenced TIFF format in two versions, with vector objects marked and unmarked. Such data can be displayed on the backdrop of other cartographic and vector materials and is also easier to use on tablets with built-in GPS when locating objects on the ground. For archaeologists working in the field, georeferenced maps in TIFF or JPG format were made that contained detailed locations of the forest compartments on a contour map. For preparing field-based materials, additional data were used, such as

- $\quad$ forest compartments and forest district boundaries layers from the Forest Data Bank;

- $\quad$ roads and waterways network layers obtained from the OpenStreetMap service;

- a Digital Terrain Model obtained from the Geodesy and Cartography Documentation Centre in Warsaw; 
- historical forest, topographic and soil maps;

- historical aerial images;

- locations and data of archival archaeological sites.

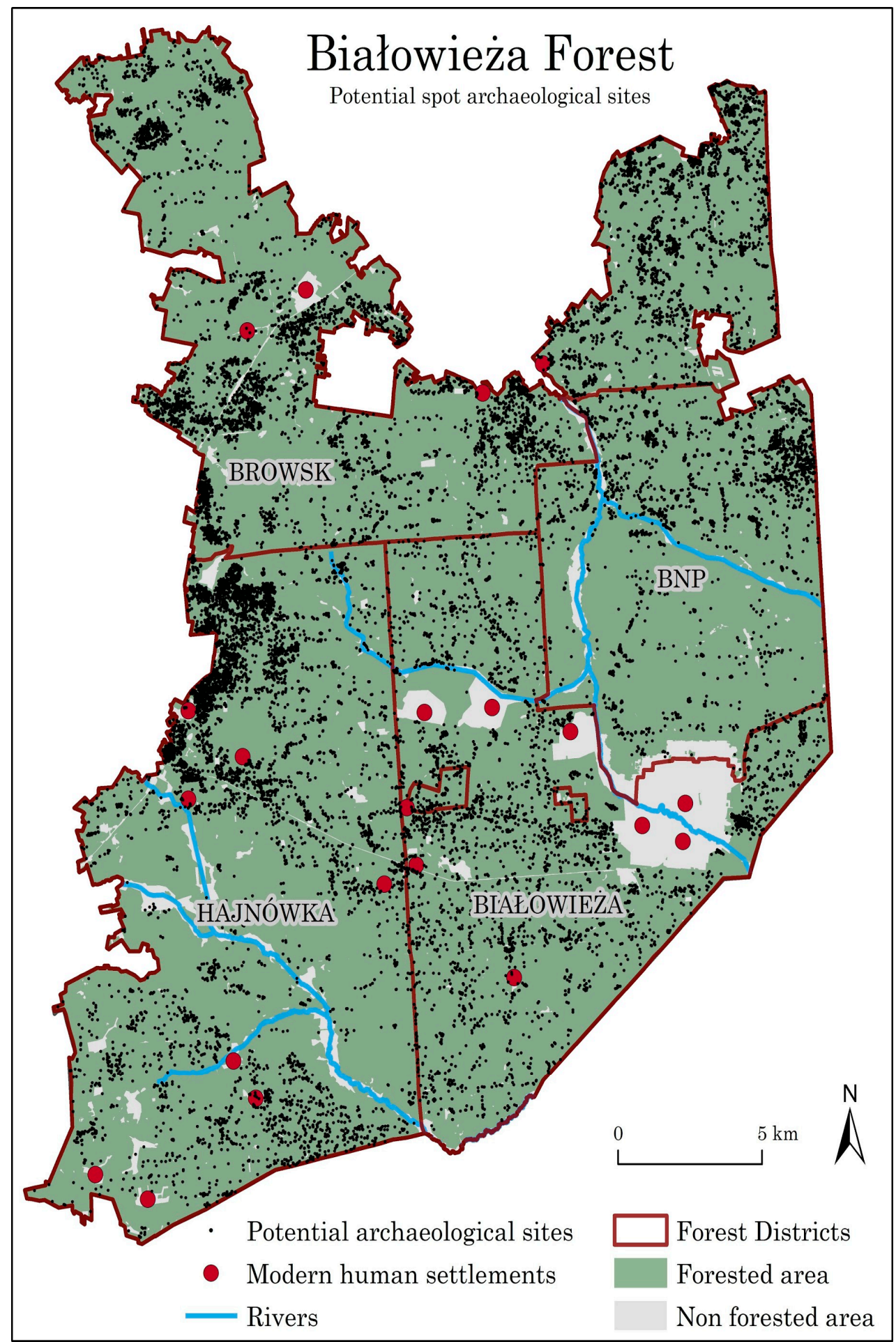

Figure 3. Map of potential archaeological objects/records—anthropogenic remains—identified using ALS data. 


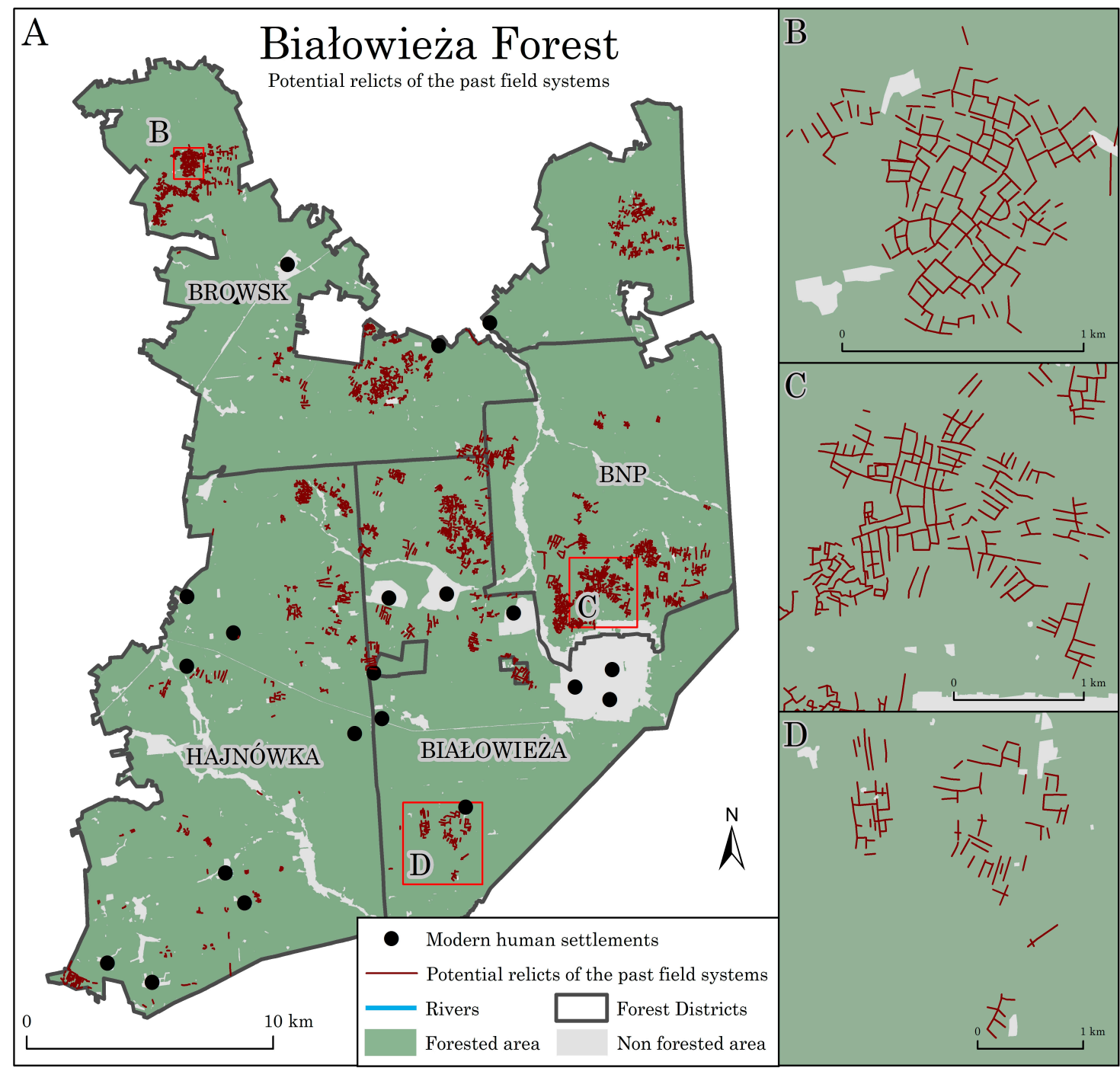

Figure 4. Map of "potential relicts of field systems" (A), identified using ALS data (B-D)—close-up of the linear remains for three sample areas.

\subsection{Systematic and Multi-Site Field Verification and Specialist Analyses}

The systematic and multi-site field verification and specialist analyses of the anthropogenic remains of agrarian systems consisted of the following steps: (1) field surveys; (2) geological drilling and/or soil coring; (3) excavations surveys; (4) soil pits; and (5) specialist analyses/laboratory analysis. As part of the fieldwork, a comparison of LiDAR data with the situation in the field was conducted.

\section{Results}

\subsection{Primary Recognition}

As a result of the primary recognition process (Section 2.6) conducted over the Polish part of the Białowieża Forest, more than 20,000 potential archaeological features (single archaeological objects-features such as barrows, etc.) or sites (for example several features in a group) were identified (Figure 3). In addition, approximately 4000 so-called "potential linear objects" were found (Figure 4)—and were mostly field system remnants. Table 1 lists the potential archaeological objects identified in each administrative unit by the team of interpreters. We cannot treat these first recognition results as archaeological remains. There are potential archaeological sites that were subject to additional field verification. 
Table 1. Summary of the potential archaeological objects detected based on DTM interpretation (first stage-2016).

\begin{tabular}{lrr}
\hline Administrative Unit & Point Objects * & Linear Objects ** \\
\hline Białowieża Forest District & 3519 & 980 \\
Browsk Forest District & 7572 & 1449 \\
Hajnówka Forest District & 6761 & 521 \\
Białowieża National Park & 2811 & 890 \\
\hline TOTAL & $\mathbf{2 0 , 6 6 3}$ & $\mathbf{3 8 4 0}$
\end{tabular}

*-Potential archaeological features (such as barrows, charcoal kilns, etc.) or contemporary anthropogenic objects or unspecified objects). ${ }^{* *}$-Potential archaeological features or contemporary anthropogenic objects or unspecified objects with their own landscape sculpture (with different widths of elevation, ridges or faults-especially potential remains of field boundaries (among other banks and lynchets demarcating the fields)).

Among these, clusters-groups of linear ridges—-were specified, defining the polygonal (usually irregular quadrilateral) surfaces (Figure 4). Similar arrangements are known from the literature and are identified with ancient agricultural systems- "field systems", "lynchets" or "Celtic fields" [53-56]—whose existence has also been confirmed by other research teams for the Białowieża Forest [57]. A similar diagnosis of old agricultural systems (and similar elements of this type of construction, e.g., copper) is shown in numerous studies, including those that use ALS data [58-63]. There were at least two types of systems observed with the linear elevations: (1) with an irregular concentric system and (2) with more regularly arranged forms. Numerous objects occurred separately, or apart from clusters, which in many situations could be associated with the destruction of more substantial deposits. Some of these objects are probably the remains of otherwise undetected human activities in the distant past.

\subsection{Fieldwork Verification}

During 2016 [19,64,65] and especially during 2017-2019 [66-68], we carried out an extensive campaign of field work, including archaeological surveys, test-pits and excavations. Detailed results of the abovementioned research will be published in separate publications-in this manuscript we are concentrating only on linear ridges, or remains of field systems. The aim of the field verification work was to confirm the origin and role of the potential archaeological sites detected on the ALS-based DTM.

The most important group of objects was related to clusters of linear elevations (ridges) purely seen in the field (Figure 5), defining the polygonal (usually irregular quadrilateral) surfaces (Figures 4 and 5). More than $300 \mathrm{~km}$ of linear ridges, individual or grouped into polygonal surfaces (or occurring outside of groups), could be clearly identified based on the ALS data (Figure 5B,D). The objects are mainly present on local hills (raised areas). This can be connected to agricultural land-use patterns since these features are not found within floodplain zones-above the flood areas (Figure 5A). Linear ridge systems cover a large area of the BF. Based on the ALS data, the total area of clusters is over 2500 ha (Figure 4), which is approximately $4 \%$ of the entire Polish part of the Białowieża Forest. The area of object complexes in the Białowieża National Park is approximately 1500 ha, which represents approximately $14.3 \%$ of its total area.Numerous objects occurred separately, or apart from clusters, which in many situations could be associated with the destruction of more substantial deposits.

The verification concentrated on selected remains of the field systems based on archaeological surveys (Table 2). These were identified on the ground primarily based on small linear elevations-ridges from a few to several dozen centimetres in height with widths of up to a few metres and lengths often exceeding $100 \mathrm{~m}$ (Figures 5-7). A total of 1232 out of 1328 of the linear objects interpreted as linear ridges were positively verified (potential remains of banks or lynchets demarcating the fields) by recognizing and documenting the course of the objects in the field, also in the area of the BPN [67]. 

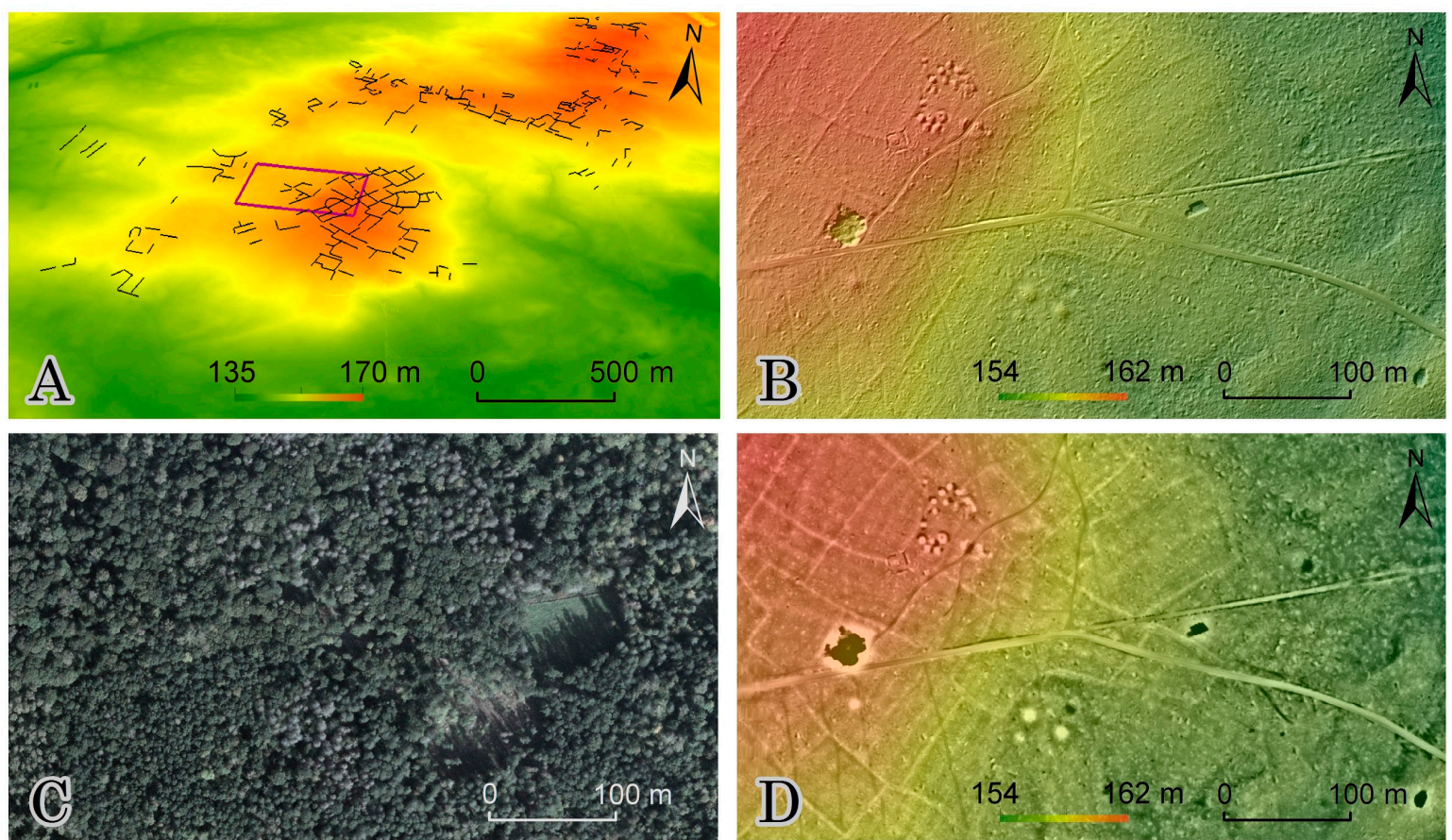

Figure 5. An overview of the remains of field systems. Notice that they occur mainly on hills (A). The objects are under the forest canopy presented (C) and were detected using digital terrain model processing, such as hillshade (B) and the local relief model (D).

Table 2. A summary of the basic information on linear elevations-potential remains of former agricultural systems in the Polish part of the Białowieża Forest, identified based on ALS data.

\begin{tabular}{lr}
\hline \multicolumn{1}{c}{ Description } & Summary \\
\hline Total number of linear ridges recognized in the ALS data in 2016. & 3840 \\
Total (estimated) length of recognized linear ridges_-potential remains of & $300 \mathrm{~km}$ \\
former fields & 1328 \\
$\begin{array}{l}\text { Number of selected linear elevations for field verification (single linear ridges) } \\
\text { Positively verified (surface field verifications) of linear elevations in the field } \\
\text { (single linear ridges) }\end{array}$ & 1232 \\
$\begin{array}{l}\text { Total—approximate area of the land on which linear ridges were identified on the } \\
\text { basis of the ALS database, together with areas within the linear ridges } \\
\text { (potential fields, pastures, etc.) }\end{array}$ & 2500 ha \\
\hline
\end{tabular}

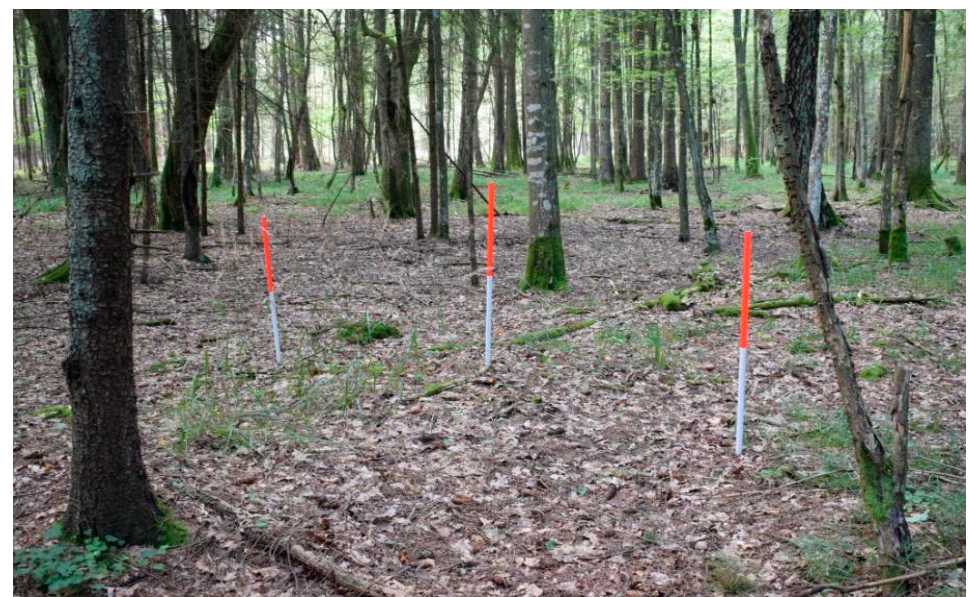

Figure 6. Remains of the field systems identified based on field verification-archaeological survey, summer 2017 (linear ridge). The ranging poles are graduated every $0.5 \mathrm{~m}$. Photo: S. Wajda. 


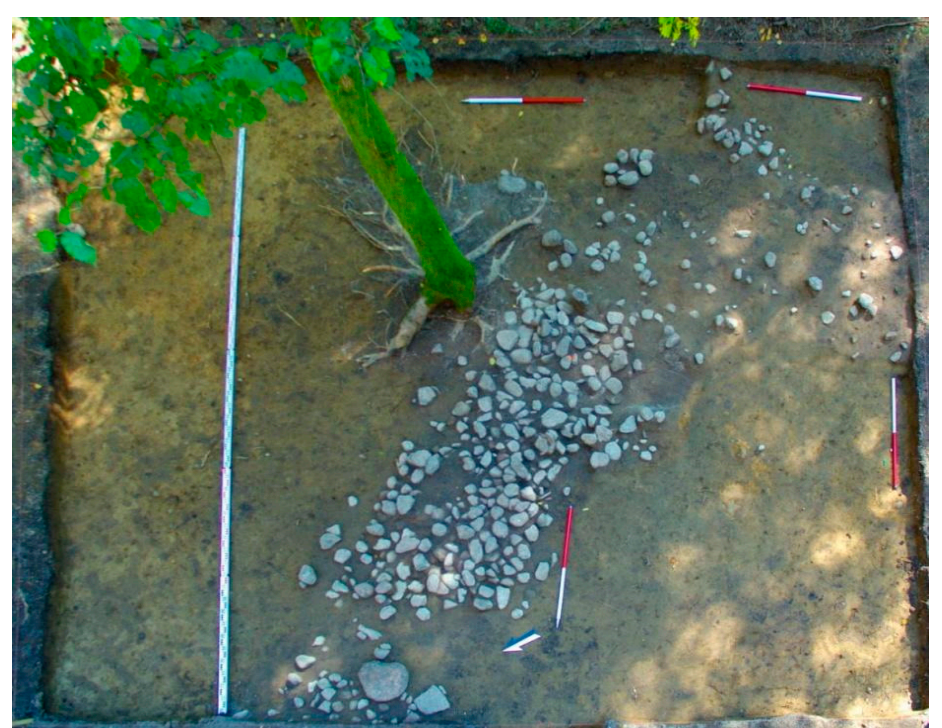

Figure 7. Białowieża Forest. Remains of a field boundary. The ranging poles are graduated every $0.5 \mathrm{~m}$. Photo: A. Duda.

In many places, the readability of the objects was poor, which affected their exact field documentation. This situation is related to the destruction of objects either by human activities or by environmental processes. In many places, clusters of stones were lying on the ground surface, either directly on the line of a ridge or in its close vicinity, or even moved from their original locations (Figure 8). Field observations of existing trees indicated that these objects had been created before the extension of the forest in those areas.

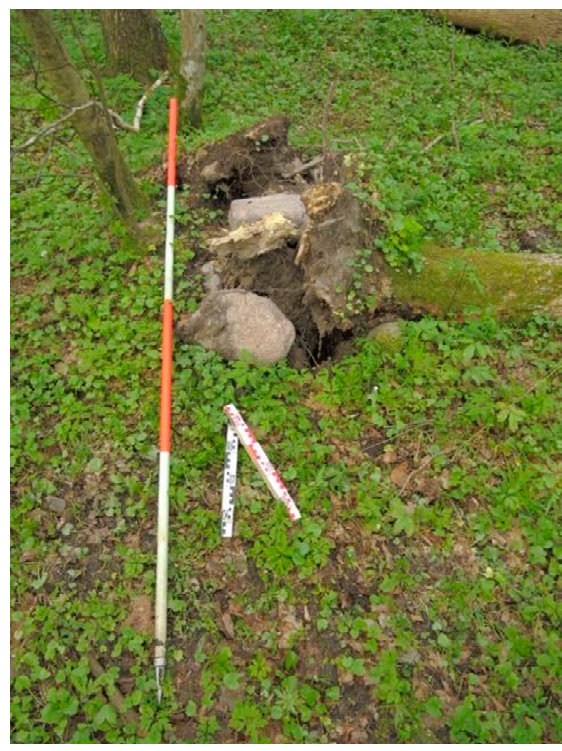

Figure 8. Example of a cluster of stones, September 2017. Location: near the linear ridges-recognition based on ALS data. The ranging pole is graduated every $0.5 \mathrm{~m}$. Photo: R. Zapłata.

Additional activities (mainly from 2017), apart from field verification, related to the recognition of linear objects consisted of

- 91 soil test pits;

- 77 archaeological test trenches;

- laboratory analysis. 
A detailed presentation of the results of the field is the subject of a separate study in progress. Below we summarize the general results.

Soil pits, which revealed the stratigraphic positions of individual objects, provided materials for special analyses. The first surveys and excavations were carried out in 2016 [19,64,65], but only two linear elevations were surveyed, of which only one was considered anthropogenic, omitting pedological studies. Verification of the results of these earlier studies was carried out in 2017 and 2018, which resulted in clear indications of the anthropogenic nature of the linear elevations. For 77 excavations (test-pits-trenches) in 2017-2019 (Figure 9), and soil excavations (91 soil outcrops-pedological transects), the stratigraphic system was confirmed, indicating the anthropogenic character of the elevations. The aforementioned invasive (excavation) examinations have verified over 50 linear elevations-so-called "balks" - in the area of the five largest clusters of the so-called post-farming facilities within the area of the BF.

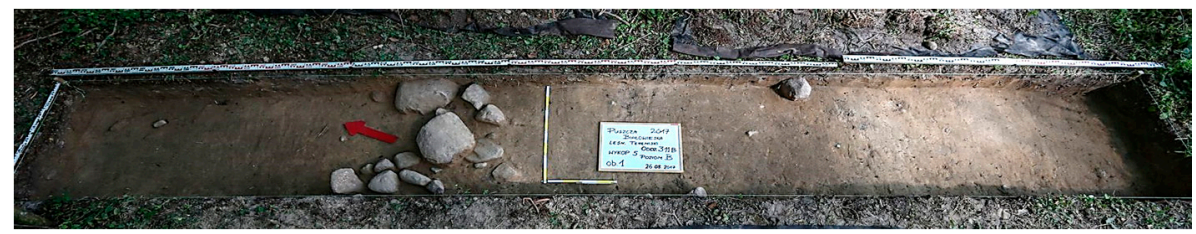

Figure 9. An example of an open survey excavation. Photo: E. Kuciewicz.

As part of the invasive intensive fieldwork, 91 test pits were made in transects (3 pits in each transect) in order to carry out physico-chemical soil analyses. Volumetric analysis, aimed at determining differences in the degree of soil compaction, and the measurement of the share and vertical distribution of carbon and nitrogen in soils up to $70 \mathrm{~cm}$ deep, were used as indicators of soil transformation under the influence of cultivation or fertilization. Out of the 66 pits from 2017, more than half had confirmed significant changes in the vertical distribution of carbon and nitrogen in relation to soils with confirmed natural regeneration and forest management origins [69].

Laboratory analyses allowed, inter alia, to confirm a pre-arranged chronology-C14-dating, following a sample taken from (Figure 10): (1) one of the objects (linear ridge) (95.4\% probability), a 662 calibrated date $\mathrm{AD}$ to 770 calibrated date $\mathrm{AD} /(68.2 \%$ probability $) 672$ calibrated date $\mathrm{AD}$ to 765 calibrated date $\mathrm{AD} ;(2)$ a second archaeological object (prehistoric hearth located in the linear ridge) $(95.4 \%$ probability), a 138 calibrated date $\mathrm{AD}$ to 339 calibrated date $\mathrm{AD} /(68.2 \%$ probability) 223 calibrated date AD to 329 calibrated date AD [70]; and (3) from a place near the field systems ( $95.4 \%$ probability), a 43 calibrated date $\mathrm{BC}$ to 125 calibrated date $\mathrm{AD} /(64.6 \%$ probability) 1 calibrated date $\mathrm{BC}$ to 82 calibrated date $\mathrm{AD}[71]$.

In contrast with the literature on the subject, remains of former fields can be initially associated mainly with the period of Roman influence. The settlement context, recognizing archaeological sites and other factors, also indicate a chronology within the pre-Roman period from the 5th century BC to about the 1st century AD (e.g., Figure 4D). Recognized field systems are dated mainly from about the 1st/2nd century to the 4 th century AD. These field systems can be identified as associated with the activities of the Wielbark culture population, while the objects can be associated with the chronologically younger Slavic communities from the period of the 6th-13th century AD. In relation to some of these linear ridges and polygonal spaces, one should also consider the remains of modern constructions. A detailed presentation of the results of field and laboratory tests is the subject of a separate study (in progress). The results of the work are also the basis for further work on the reconstruction of former agricultural systems in the Polish part of the BF based on the acquired spatial data and results of field verification. In some places, linear ridges lie under mounds dated to the early Middle Ages, which allows determining a relative chronology of the fields-the period before the early Middle Ages (Figure 11). 


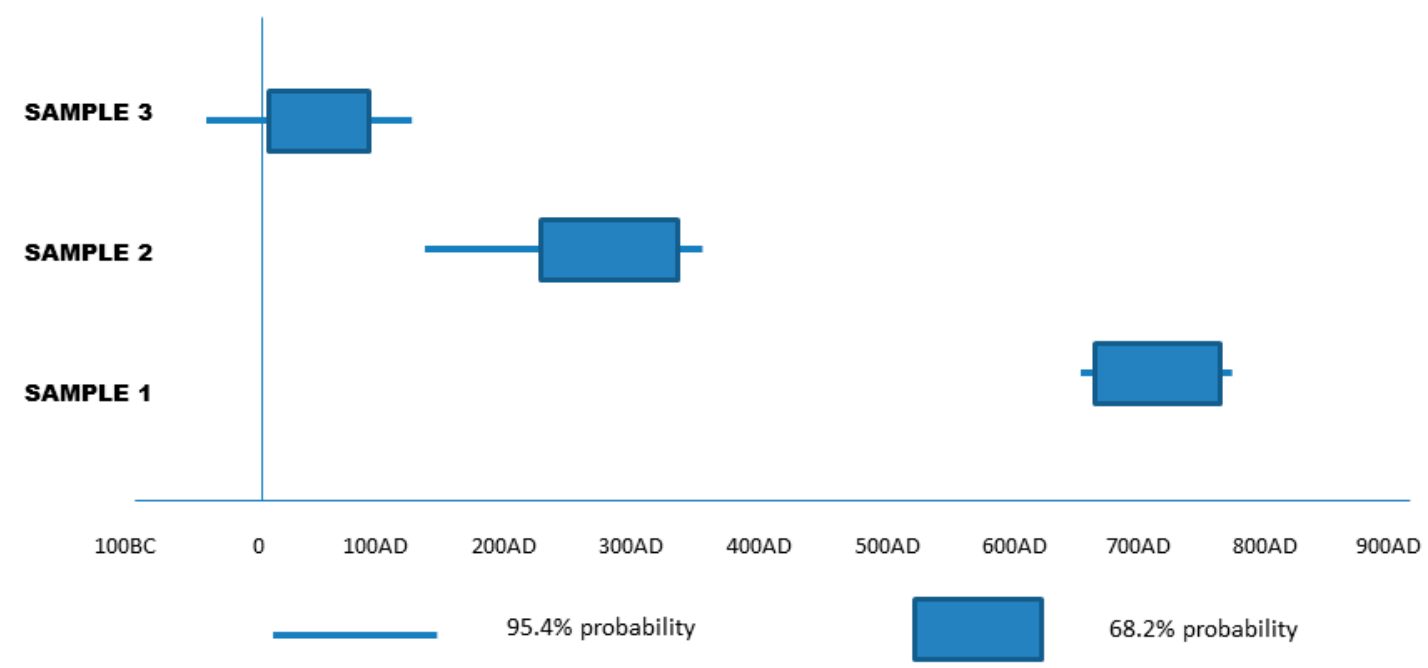

Figure 10. Summary of the dating results of three samples related to the tested field systems in the Białowieża Forest. Source: Goslar 2018 and Krapiec 2019.
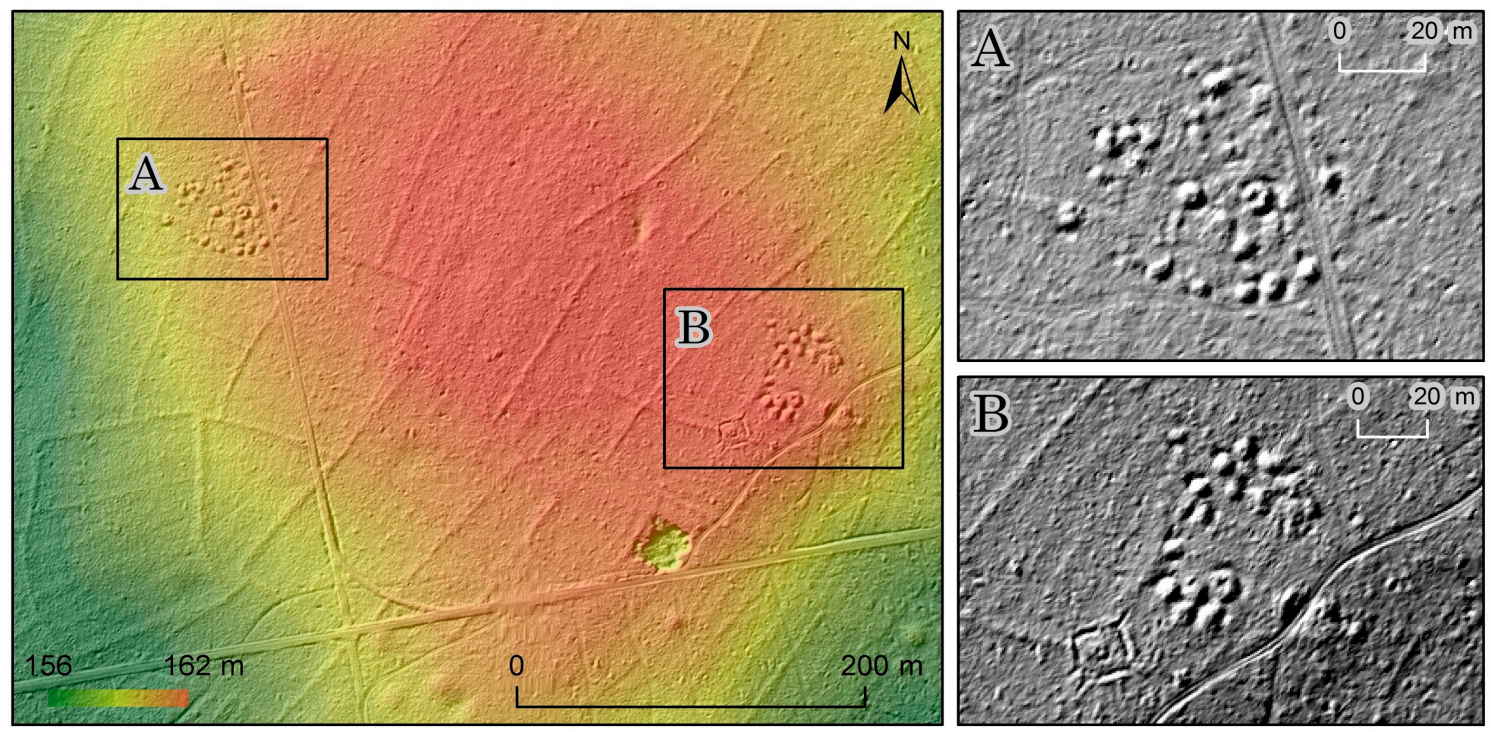

Figure 11. An example of a case where the linear elevations lie under mounds (A) dated to the early Middle Ages and under other historical objects—charcoal piles (B). As a background the DTM is shown (left image), as well the hillshade DTM (right images) is shown.

Not all linear elevations in the ALS data have been recognized as potential historical objects if their deterioration were too great to recognize them in the field. Furthermore, it is possible that some land elevations may not be related to the post-agricultural clusters. Up to this point, the study of a larger area than the BF territory has not been possible.

\section{Discussion}

The application of remote sensing technology for discovering ancient human settlements has developed into an expanding field of research. Our study presents a comprehensive analysis involving the use of ALS in a UNESCO site. We identified a large body of unknown archaeological objects and discovered numerous traces of past human activities in the Polish part of the BF. Many objects were verified in situ (Figure 12). 

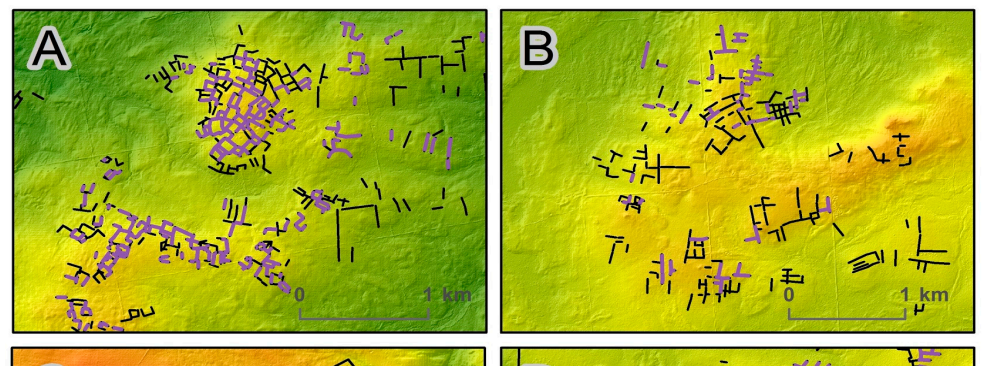

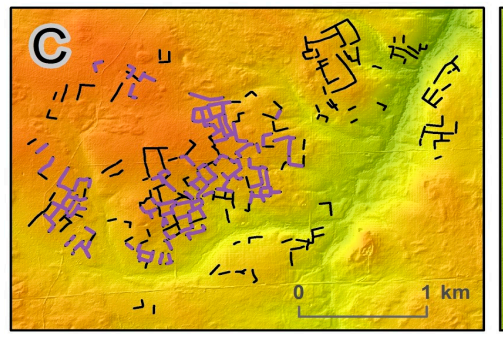

Linear archaeological objects confirmed

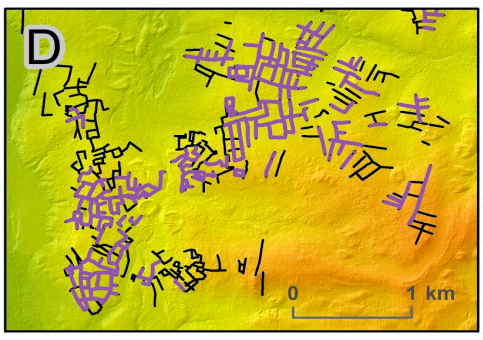

132 Elevation $[\mathrm{m}] \quad 196$

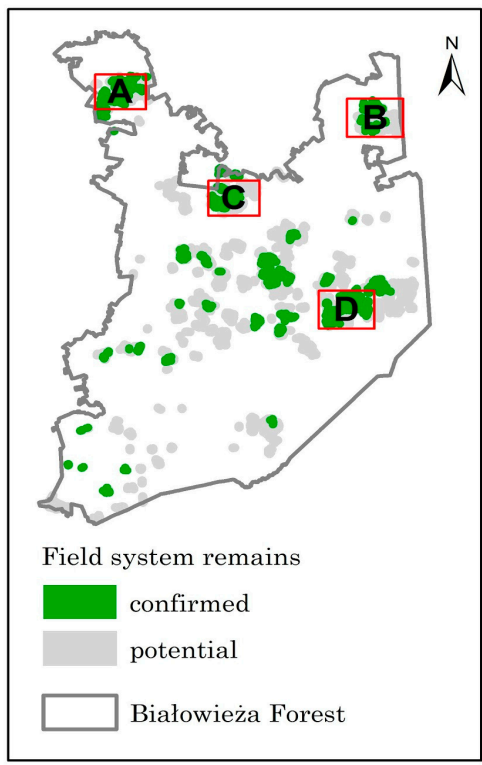

Figure 12. The linear objects (A-D) confirmed in the field (violet line) and marked as a remains of field systems. Only selected groups of potential linear objects (green polygons on the right map) were verified in the field. Grey polygons were not verified yet.

Our findings represent new evidence of extended human activity in the history of the BF in addition to that published in 2016 [65]. The most interesting of the identified objects are remains of former settlement and field systems (Figure 11), forming four-sided or polygonal separated areas that are primarily visible in the form of linear deformations or ridges and arranged in compact assemblages. The archaeological objects that could be identified were based on their own landscape sculpture (linear or point) with different widths of elevation, ridges or faults. We assume (based on analogies from the literature $[51,55,56,72]$ ) that they represent the remains of ancient field systems (especially as an irregular accreted field or coaxial fields). The linear deformations and ridges are probably the remains of field boundaries, banks and lynchets demarcating the fields or fences, field roads, clearing cairns, ridges or plough headlands. The shape of these structures, known from numerous other studies [52,53,68-74], indicates their anthropogenic origin. Objects of this type-remnants of former agricultural systems-are referred to as field systems with distinct linear elevations and specific, closed spaces in the form of multi-dimensional structures varying in size from a few-dozen to over a $100 \mathrm{~m}$ long. These objects can also be associated with the results of palynological research, especially in the BF area, which indicates agricultural activity during the period of Roman influence (the 1st century AD to about the 4th century AD) [8].

Our research confirmed in many places the unnatural anthropogenic nature of the stratigraphic units, which is evidenced by, for example, a clear elevation in the central part (visible in the cross-section of objects) and a greater thickness of specific layers (stratigraphic units) in relation to the edge of the elevation. Some objects were also characterized by erratic stone placements found within and in many cases arranged intentionally in the central part of the elevation. Such structure systems show similarity to other objects known from the literature on the subject, which are remnants of former field systems in Europe [75-77]. Additionally, artefacts (fragments of ceramic vessels and metal items) were acquired in several excavations, chronologically bound (based on artefact dating) to the Roman period (the 1st century AD to about the 4th century AD) and younger periods. The thickness of the layers occurring directly under the contemporary layer, or even under the bedding, at the elevation of the ridge, is larger than at the edges, and gradually decreases towards the base of the ridge [66].

An important issue regarding this research in forest areas seems to be the quality of the ALS data $[30,35]$, especially the use of publicly available resources, which have become available in many countries, especially in Europe. We need to take into account that some of these data have sparse 
density, which does not allow for a detailed investigation. Our data were much better than the previously existing resources from national surveys (Figure 13). The used data were more than two times denser and covered the whole Polish part of the BF area.

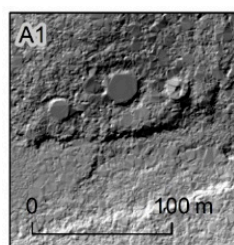

A2.

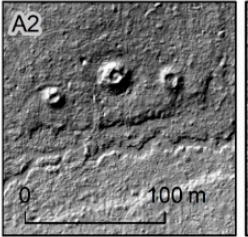

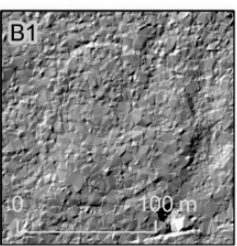

B2
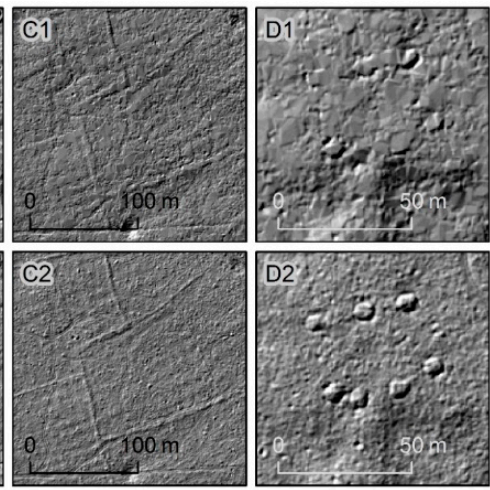

Figure 13. Compare two different hillshades rasters. First, (A1-D1) processed from ALS point cloud with an average density of approximately $4 \mathrm{pts} / \mathrm{m}^{2}$ on the leaf-on season (ISOK data); secondly, (A2-D2) from ALS point cloud with average density above $11 \mathrm{pts} / \mathrm{m}^{2}$ (LIFE+ ForBioSensing project) on the leaf-off season. From left: borrows (A), hillfort (B), remains of the past agricultural system (C), and charcoal piles (D). Object recognition varies depending on its size and structure. The pixel size for both datasets is $0.5 \mathrm{~m}$.

In a large area analysis, including regions with limited access, such as the Białowieża Forest and other UNESCO sites, it is essential to use non-invasive technologies that allow remote analysis and monitoring. Forest areas require very specific, individual approaches to make the best use of available technology and data, including flights (in areas with low point cloud coverage, dense vegetation or seasonal water bodies) with the use of Unmanned Aerial Vehicle Laser Scanning (UAV-LS) or Mobile Laser Scanning (MLS), in order to fill data gaps or improve data quality [78,79].

We used visual interpretation, which is accurate but time-consuming and requires experienced human resources [45]. Automated methods could provide additional cognitive value. Methods such as machine learning or neural networks are already in use [80-84] and will be explored in the future. Since we have already verified the results in the field, we may have reference materials for automated solutions evaluation. There is still a significant group of potential historic features that have not been either a subject to ALS data interpretation or field verification, nor to a more complete inventory. Many of those do not have strong topographic signatures or are under the surface, which could be detected with ALS, and need more dense point clouds (i.e., UAV-LS) or additional technologies (e.g., geophysics methods) for their detection and recognition.

Another important issue is the primary detection and analysis of resources in sensitive areas where there are real threats to archaeological monuments, whether as a result of natural processes or human activities. Especially in case of large-scale human activities, it is reasonable to initially carry out, for example, ALS/UAV-LS data acquisition and interpretation in such places and to create and share spatial data with possible/verified archaeological heritage detected. Further, priority should be given to areas where natural processes destroying cultural heritage are taking place, such as landslides, windbreaks and emerging excavations; some are found in the Białowieża Forest.

ALS has been used recently in many countries to uncover human activity and settlements in the past [85-89]. This is a testimony of often unknown actions in areas that are often considered or were so-called settlements in the past. Our research has provided a multitude of evidence confirming that the Białowieża Forest was modified by human activities during ancient times in ways not known before. Bush et al. $[90,91]$ revealed a 6900-year history of landscape modification by humans in lowland Amazonia, where humans had changed the forest structure and composition as a result of extensive agriculture. Fisher et al. [92] identified ancient settlement patterns using LiDAR in the Mosquitia 
Region of Honduras and other teams identified ancient settlement patterns in northern Guatemala [93], Central [94] and North America [95].

The evidence gathered in this study contributes significantly to global research of archaeological sites in forested regions. It seems that there is a large gap in our knowledge of the history of many parts of the world that remain under forest cover. The evidence provided in our study contributes to a new understanding of human activity in Białowieża [96] and provides the basis for more detailed analysis in the future.

\section{Conclusions}

The extent of the area and the impact of human activities in the Polish part of the BF was substantially greater than previously believed. Substantial evidence was found of human settlement and agriculture during the Roman period (1st century AD to approximately 4th century AD) and/or sometime in the Early Medieval Ages (6th-13th century AD). The remains that have been preserved probably constitute only a part of the multitude of objects that once existed in this area, and potentially also within the Belarusian part of the BF. Some objects have been destroyed, and some were not detected due to the limited quality of the ALS data, which can be related to the specific natural conditions prevailing in some areas of the BF.

An additional product of this study is the established database, the Cultural Heritage-GIS Puszcza Białowieska (CH-GIS Białowieża Forest), as well as a derivative of the abovementioned Web-based geoportal "Natural and cultural portal Puszcza Białowieska"|"Natural and cultural heritage portal of the State Forests" (https://puszcza-bialowieska.lasy.gov.pl/)—allowing for the sharing of resources and promoting the dissemination of research results. This work is part of a broad interdisciplinary effort in Poland, which includes other forests and protected areas, including the Magurski, Roztoczański and Bieszczady National Parks [78-80]. The inventory and monitoring of cultural resources in forest areas represents an emerging research area of global dimensions.

We could verify more than 1300 linear objects in the field, thus opening a new chapter in the study of archaeological sites in the Białowieża Forest. The activities confirm the need to undertake further research that takes into account the current state of knowledge about the cultural heritage of the Bialowieza Forest. The goal of subsequent work should be to identify the resources in detail, learn about the history of the area, and effectively manage the UNESCO World Heritage site-for integrated management of the cultural and environmental goods and services.

Author Contributions: K.S. and R.Z. designed the study concept and methodology; K.S. and R.Z. coordinated the research activities leading to this publication; K.S. and R.Z. were responsible for getting the financial support and for the project leading; B.K. and J.W. prepared the data for interpretation; M.M., J.W., M.B., G.K., Ł.K., K.M., A.M. (Aneta Modzelewska), K.P. (Karolina Parkitna), Ż.P., K.P. (Kamil Pilch), K.R., R.S., M.W., P.R. analysed and interpreted the ALS-based data; B.K., A.M. (Anna Markiewicz) and R.Z. evaluated the results of the interpretation; KS wrote the first version of the manuscript; all authors, especially R.Z., K.v.G. and C.J.C., provided critical review, commentary and revision of the first version of the manuscript. All authors have read and agreed to the published version of the manuscript.

Funding: This study (since 2016) was supported by the following projects, funded by the General Directory of State Forests: "Assessment of biodiversity in Białowieża Forest based on selected natural and cultural elements" (2016) and "Assessment of biodiversity in Białowieża Forest based on selected natural and cultural elements-Continuation" (2017-2019).

Acknowledgments: Data for this project were acquired under the project "LIFE + ForBioSensing PLComprehensive monitoring of stand dynamics in Białowieża Forest supported with remote sensing techniques" which is co-funded by the EU Life Plus programme (contract number LIFE13 ENV/PL/000048) and the National Fund for Environmental Protection and Water Management in Poland (contract number 485/2014/WN10/OP-NM-LF/D). The field verification of the identified archaeological sites and feature in 2016, 2017-2019 was carried out under the direction of Rafał Zapłata, who was the task coordinator in 2016 and 2017-2019, as well as head of some field surveys and geophysical prospecting and excavation research since 2017 (in cooperation with the Institute of Archaeology and Ethnology, Polish Academy of Sciences (IAE PAN) in 2016, and the Hereditas Foundation in 2017-2019); and Dariusz Krasnodębski, who was the field research coordinator in 2016 (IAE PAN). Research in 2016 under the direction of IAE PAN was conducted by a team composed of H. Olczak, W. Małkowski, A. Małkowska, R. Ryndziewicz, J. Piątkowska-Małecka, G. Skrzyński, Ł. Wisławski, T Herbich, J. Mizerka, A. Pyzik, E. Warchał, 
H. Semianchuk, S. Lech. I. Taranta, J. Kowalczyk, M. Grzybczyk, M. Bryńczak, M. Krzyżak, M. Romanowicz, Z. Tragarz, M. Seczkowska, A. Wawrusiewicz, I. Kryński, K. Haracz, A. Piasecki, and K. Piasecka. In 2017-2019 the field research was carried out under the direction following persons: Sylwia Wajda (coordinator some of surface and geophysical surveys, in cooperation with the Hereditas Foundation); Michał Pawleta (research manager of excavations in 2017, in cooperation with the Hereditas Foundation); Ewa Kuciewicz (excavation research manager in 2017); Jakub Affelski (excavation research manager in 2017) (name of the company in Polish: Szpila Pracownia Archeologiczno-Konserwatorska Jakub Affelski); Piotr Olejarczyk (excavation research manager in 2017) (name of the company in Polish: PAPO Pracownia Archeologiczna); and Jarosław Lepiejza (archaeology research manager in 2017) (name of the company in Polish: Pracownia Archeologiczna Jarosław Lepiejza); Paweł Kaźmierczak (excavation research manager in 2018 and 2019); Ewa Kwiatkowska (excavation research manager in 2018 and 2019). Soil research in 2017 was carried out under the direction of Marek Ksepko and Janusz Porowski of the Bureau for Forest Management and Geodesy, Białystok Regional Office. Geophysical prospecting was carried out under the direction of: (1) Wiesław Małkowski, Tomasz Herbrich and Robert Ryndzewicz in 2016; (2) GeoFusion in 2017 (team leader Łukasz Porzczek); (3) GTT in 2017 (team leader Michał Pisz and Piotr Kaczmarczyk). UAV-LiDAR in 2018 was carried out under the direction Jacek Krawiec Laser-3D, in cooperation with LiDAR3D. Research in 2017-2018 and in 2019, under the direction of the Hereditas Foundation, was carried out in cooperation with the specialists mentioned above as well as Janusz Czerepko (with the IBL team) Grzegorz Skrzyński, Krzysztof Narloch, Kamil Niemczak, Anna Krukowska, Paweł Krukowski, the ArcheoService firm, Ewa Kwiatkowska, Marek Grześkowiak firm, Dominika Majchrzak, Aleksandra Zaleska, Anna Wilk, Jerzy Cisatek, Adriana Ciesielska, Hubert Dziewiczkiewicz, Katarzyna Harabasz, Agnieszka Jarzec, Aleksandra Majecka, Marek Makola, Łukasz Karol, Sławomir Miłek, Ewelina Mista-Jakubowska, Anna Myszka, Jacek Tomczyk, Artur Obidzisńki, Elżbieta Pelpińska, Joanna Piątkowska-Małecka, Łukasz Reczulski, Jakub Stepnik, Joanna Stohandel, Aleksandra Tobiasz, Adam Wawrusiewicz, Daria Wyrostkiewicz, Robert Wyrostkiewicz, Mateusz Zawadzki and students, manual workers and volunteers. Scientific and organizational consultations in 2017-2019 were conducted by Joanna Kalaga, Jakub Lewicki and Jacek Hilszczański.

Conflicts of Interest: The authors declare no conflict of interest.

\section{References}

1. Fiedukowicz, A.; Głażewski, A.; Kołodziej, A.; Koszewski, K.; Kowalski, P.; Olszewski, R.; Włochyński, L. Map portal as a tool to share information on cultural heritage illustrated by the national heritage board geoportal. In Advances in Digital Cultural Heritage; Springer: Funchal, Madeira, Portugal, 2018; pp. 48-64.

2. Oniszczuk, A.; Makowska, A. Archaeological data in the gis portal of the national heritage board of poland. Internet Archaeol. 2017, 43. [CrossRef]

3. Bristow, R.S.; Therien, A. Discovering archaeological landscapes in parks and protected areas. N. Am. Archaeol. 2019, 40, 99-115. [CrossRef]

4. Corns, A.; Shaw, R. Lidar and World Heritage Sites in Ireland: Why was such a rich data source gathered, how is it being utilised, and what lessons have been learned. In Interpreting Archaeological Topography. Airborne Laser Scanning, 3D Data and Ground Observation; Opitz, R.S., Cowley, D.C., Eds.; Oxbow Books: Oxford, UK, 2013; pp. 146-160. [CrossRef]

5. Opitz, R.S.; Cowley, D.C. Interpreting archaeological topography: Lasers, 3D data, observation, visualisation and applications. In Interpreting Archaeological Topography. Airborne Laser Scanning, 3D Data and Ground Observation; Opitz, R.S., Cowley, D.C., Eds.; Oxbow Books: Oxford, UK, 2013; pp. 1-12. [CrossRef]

6. Megarry, W.P.; Davenport, B.A.; Comer, D.C. Emerging applications of lidar/airborne laser scanning in the management of world heritage sites. Conserv. Manag. Archaeol. Sites 2016, 18, 393-410. [CrossRef]

7. Gallagher, J.M.; Josephs, R.L. Using LiDAR to detect cultural resources in a forested environment: An example from Isle Royale National Park, Michigan, USA. Archaeol. Prospect. 2008, 15, 187-206. [CrossRef]

8. Zimny, M.; Latałowa, M.; Pędziszewska, A. Późnoholoceńska historia lasów rezerwatu ścisłego białowieskiego parku narodowego In Lasy Rezerwatu Ścisłego Białowieskiego Praku Narodowego; Keczyński, A., Ed.; Białowieża National Park: Białowieża, Poland, 2017; pp. 30-59. (In Polish)

9. Jaroszewicz, B.; Cholewińska, O.; Gutowski, J.M.; Samojlik, T.; Zimny, M.; Latałowa, M. Białowieza forest-a relic of the high naturalness of European forests. Forests 2019, 10, 849. [CrossRef]

10. Mitchell, F.J.G.; Cole, E. Reconstruction of long-term successional dynamics of temperate woodland in Bialowieza Forest, Poland. J. Ecol. 1998, 86, 1042-1059. [CrossRef]

11. Górska, I. Badania archeologiczne w Puszczy Białowieskiej. [Archaeological investigations in Bialowieza Forest] Archeol. Pol. 1976, 21, 109-134. (In Polish)

12. Hedemann, O. L'histoire de la foret de Białowiezża jusqu'a 1798 (The history of the forest of Białowiezża before 1798). Inst. Rech. For. Doman. Warszawa Trav. Comptes Rendus Ser. A 1939, 41, 310. 
13. Franklin, S. Białowieża forest, Poland: Representation, myth, and the politics of dispossession. Environ. Plan. A 2002, 34, 1459-1485. [CrossRef]

14. Niklasson, M.; Zin, E.; Zielonka, T.; Feijen, M.; Korczyk, A.F.; Churski, M.; Samojlik, T.; Jędęrrzejewska, B.; Gutowski, J.M.; Brzeziecki, B. A 350-year tree-ring fire record from Białowieza primeval forest, Poland: Implications for central European lowland fire history. J. Ecol. 2010, 98, 1319-1329. [CrossRef]

15. Sunseri, T. Exploiting the Urwald: German post-colonial forestry in Poland and central Africa, 1900-1960. Past Present 2012, 214, 305-342. [CrossRef]

16. Więcko, E. Puszcza Białowieska; Państwowe Wydawnictwo Naukowe: Warsaw, Poland, 1972; p. 193. (In Polish)

17. Kuijper, D.P.J.; Jędrzejewska, B.; Brzeziecki, B.; Churski, M.; Jędrzejewski, W.; Żybura, H. Fluctuating ungulate density shapes tree recruitment in natural stands of the Białowieża Primeval Forest, Poland. J. Veg. Sci. 2010, 21, 1082-1098. [CrossRef]

18. Goetze, A. Archäologische Untersuchungen im Urwalde von Bialowies; Verl. der Bayer. Akad. der Wiss: Muünchen, Germany, 1929; Available online: http://www.worldcat.org/title/archaologische-untersuchungenim-urwalde-von-bialowies/oclc/313608484 (accessed on 14 June 2020). (In German)

19. Krasnodębski, D.; Olczak, H. Badania archeologiczne na terenie polskiej części Puszczy Białowieskiej-stan obecny, problemy i perspektywy. Biul. Konserw. Województwa Podl. 2012, 18, 145-168. (In Polish)

20. Więcko, E. Puszcza Białowieska; Państwowe Wydawnictwo Naukowe: Warszawa, Poland, 1984; pp. 1-309. (In Polish)

21. Samojlik, T. Traditional utilisation of Białowieża Primeval Forest (Poland) in the 15th to 18th centuries. Landsc. Archaeol. Ecol. 2010, 8, 150-164.

22. Samojlik, T.; Fedotova, A.; Kuijper, D.P.J. Transition from traditional to modern forest management shaped the spatial extent of cattle pasturing in Białowieża Primeval Forest in the nineteenth and twentieth centuries. Ambio 2016, 45, 904-918. [CrossRef]

23. Krasnodębski, D.; Olczak, H.; Samojlik, T. Wczesnośredniowieczne Cmentarzyska w Puszczy Białowieskiej. In Silvis, Campis et Urbe; Kotowicz, W.P., Ed.; Rzeszów: Sanok, Poland, 2010; pp. 145-174. (In Polish)

24. Samojlik, T.; Jędrzejewska, B.; Michniewicz, M.; Krasnodȩbski, D.; Dulinicz, M.; Olczak, H.; Karczewski, A.; Rotherham, I.D. Tree species used for low-intensity production of charcoal and wood-tar in the 18th-century Białowieza Primeval Forest. Pol. Phytocoenol. 2013, 43, 1-12. [CrossRef]

25. Pabian, O.; Jaroszewicz, B. Assessing Socio-Economic Benefits of Natura 2000-A Case Study on the Ecosystem Service Provided by Białowieża Forest. Output of the Project Financing Natura 2000: Cost Estimate and Benefits of Natura 2000 (Contract No.: 070307/2007/484403/MAR/B2); Institute for European Environmental Policy: Brussels, Belgium, 2009; 69p.

26. Bewley, R.H.; Crutchley, S.P.; Shell, C.A. New light on an ancient landscape: Lidar survey in the Stonehenge World Heritage Site. Antiquity 2005, 79, 636-647. [CrossRef]

27. Devereux, B.J.; Amable, G.S.; Crow, P.; Cliff, A.D. The potential of airborne lidar for detection of archaeological features under woodland canopies. Antiquity 2005, 79, 648-660. [CrossRef]

28. Doneus, M.; Briese, C.; Fera, M.; Janner, M. Archaeological prospection of forested areas using full-waveform airborne laser scanning. J. Archaeol. Sci. 2008, 35, 882-893. [CrossRef]

29. Crutchley, S. Using LiDAR in archaeological contexts: The English heritage experience and lessons learned. Laser Scanning Environ. Sci. 2009, 180-200. [CrossRef]

30. Masini, N.; Coluzzi, R.; Lasaponara, R. On the airborne Lidar contribution in archaeology: From site identification to landscape investigation. In Laser Scanning, Theory and Applications; Wang, C.-C., Ed.; Intech: London, UK, 2011; pp. 263-290. ISBN 978-953-307-205-0.

31. Zapłata, R. Nieinwazyjne Metody w Badaniu i Dokumentacji Dziedzictwa Kulturowego-Aspekty Skanowania Laserowego w Badaniach Archeologicznych i Architektonicznych; Fundacja Hereditas: Warszawa, Poland, 2013; Available online: https://fundacja-hereditas.pl/publikacje/nieinwazyjne-metody-wbadaniu-i-dokumentacji-dziedzictwa-kulturowego-aspekty-skanowania-laserowego-w-badaniacharcheologicznych-i-architektonicznych/ (accessed on 1 June 2020). (In Polish)

32. Banaszek, Ł. Przeszłe Krajobrazy w Chmurze Punktów; Wydawnictwo Naukowe UAM: Poznań, Poland, 2015. (In Polish)

33. Gojda, M.; Kobyliński, Z. (Eds.) Lotnicze Skanowanie Laserowe jako Narzędzie Archeologii; Fundacja Res Publica Multiethnica: Warsaw, Poland, 2018; Available online: https://archaeologica-hereditas.org/2020/03/08/tom11-volume-11/ (accessed on 1 June 2020). (In Polish) 
34. Masini, N.; Gizzi, F.T.; Biscione, M.; Fundone, V.; Sedile, M.; Sileo, M.; Pecci, A.; Lacovara, B.; Lasaponara, R. Medieval archaeology under the canopy with LiDAR. The (re) discovery of a medieval fortified settlement in Southern Italy. Remote Sens. 2018, 10, 1598. [CrossRef]

35. Luo, L.; Wang, X.; Guo, H.; Lasaponara, R.; Zong, Z.; Masini, N.; Wang, G.; Shi, P.; Khatteli, H.; Chen, F. Airborne and spaceborne remote sensing for archaeological and cultural heritage applications: A review of the century (1907-2017). Remote Sens. Environ. 2019, 232, 111280. [CrossRef]

36. Maślanka, M.; Wężyk, P. Podręcznik Dla Uczestników Szkoleń Z Wykorzystania Produktów LiDAR; Główny Urząd Geodezji i Kartografii: Warszawa, Poland, 2014. Available online: http://www.gugik.gov.pl/_data/assets/ pdf_file/0019/23752/PODRECZNIK_ISOK_wyd.2.pdf (accessed on 1 June 2020). (In Polish)

37. Kurczyński, Z. Airborne Laser scanning in poland-between science and practice. Arch. Photogramm. Cartogr. Remote Sens. 2019, 31, 105-133.

38. Chase, A.; Chase, D.; Fisher, C.; Leisz, S.; Weishampel, J. Geospatial revolution and remote sensing LiDAR in Mesoamerican archaeology. Proc. Natl. Acad. Sci. USA 2012, 109, 12916-12921. [CrossRef]

39. Johnson, K.M.; Ouimet, W.B. Rediscovering the lost archaeological landscape of southern New England using airborne light detection and ranging (LiDAR). J. Archaeol. Sci. 2014, 43, 9-20. [CrossRef]

40. Chase, A.; Chase, D.; Weishampel, J. Lasers in the Jungle Airborne sensors reveal a vast Maya landscape. Archaeology 2010, 63, 27-29.

41. Stereńczak, K.; Ciesielski, M.; Bałazy, R.; Zawiła-Niedźwiecki, T. Comparison of various algorithms for DTM interpolation from LIDAR data in dense mountain forests. Eur. J. Remote Sens. 2016, 49, 599-621. [CrossRef]

42. Zakšek, K.; Oštir, K.; Kokalj, Ž. Sky-view factor as a relief visualization technique. Remote Sens. 2011, 3, 398-415. [CrossRef]

43. Chase, A.F.; Chase, D.Z.; Weishampel, J.F.; Drake, J.B.; Shrestha, R.L.; Slatton, K.C.; Awe, J.J.; Carter, W.E. Airborne LiDAR, archaeology, and the ancient Maya landscape at Caracol, Belize. J. Archaeol. Sci. 2011, 38, 387-398. [CrossRef]

44. Challis, K.; Forlin, P.; Kincey, M. A generic toolkit for the visualization of archaeological features on airborne LiDAR elevation data. Archaeol. Prospect. 2011, 18, 279-289. [CrossRef]

45. Johnson, K.M.; Ouimet, W.B. An observational and theoretical framework for interpreting the landscape palimpsest through airborne LiDAR. Appl. Geogr. 2018, 91, 32-44. [CrossRef]

46. Crutchley, S. Light detection and ranging (lidar) in the Witham Valley, Lincolnshire: An assessment of new remote sensing techniques. Archaeol. Prospect. 2006, 13, 251-257. [CrossRef]

47. Falinski, J.D. Vegetation Dynamics in Temperate Lowland Primeval Forests: Ecological Studies in Bialowieza Forest; Springer: Dordrecht, The Netherlands, 1986; p. 537. [CrossRef]

48. Białowieża Forest. Available online: http://whc.unesco.org/en/list/33 (accessed on 17 September 2017).

49. LAS Specification Version 1.2. Available online: https://www.asprs.org/wp-content/uploads/2010/12/asprs_ las_format_v12.pdf (accessed on 17 August 2020).

50. Bennett, R.; Welham, K.; Hill Ra Ford, A. A comparison of visualization techniques for models created from airborne laser scanned data. Archaeol. Prospect. 2012, 19, 41-48. [CrossRef]

51. Hesse, R. LiDAR-derived local relief models-A new tool for archaeological prospection. Archaeol. Prospect. 2010, 17, 67-72. [CrossRef]

52. Kokalj, Ž.; Zakšek, K.; Oštir, K. Application of sky-view factor for the visualisation of historic landscape features in lidar-derived relief models. Antiquity 2011, 85, 263-273. [CrossRef]

53. Crawford, O.G.S. Air survey and archaeology. Geogr. J. 1923, 61, 342-360. [CrossRef]

54. Curwen, E.; Curwen, E.C. Sussex lynchets and their associated fieldways. Sussex Archaeol. Collect. 1923, 64, $1-65$.

55. Field Systems. Introduction to Heritage Assets. Historic England. 2018. Available online: https:// historicengland.org.uk/images-books/publications/iha-field-systems/heag204-field-systems/ (accessed on 1 June 2020).

56. Nielsen, N.; Holst, M.; Gadd, A.; Holst, K. The layout and internal development of celtic fields: structural and relative chronological analyses of three danish field systems. Eur. J. Archaeol. 2018, 21, 385-410. [CrossRef]

57. Wawrzeniuk, J.; Budziszewski, J.; Jakubczak, M.; Rutyna, M.; Szlązak, R.; Szubski, M.; Urbańczyk, P. Dziedzictwo kulturowe puszczy białowieskiej-wstępne rozpoznanie, in dziedzictwo kulturowe w lasach. In Dziedzictwo kulturowe w lasach; Wysocki, J., Ed.; Fundacja Archeologiczna: Warszawa-Zielona Góra, Poland, 2017; pp. 193-200. (In Polish) 
58. Humme, A.; Lindenbergh, R.; Sueur, C. Revealing celtic fields from lidar data using kriging based filtering. In Proceedings of the ISPRS Commission V Symposium, Dresden, Germany, 26-27 September 2006; Available online: https://www.isprs.org/proceedings/xxxvi/part5/paper/1241_dresden06.pdf (accessed on 1 June 2020).

59. Mayoral, A.; Toumazet, J.P.; Simon, F.X.; Vautier, F.; Peiry, J.L. The highest gradient model: A new method for analytical assessment of the efficiency of lidar-derived visualization techniques for landform detection and mapping. Remote Sens. 2017, 9, 120. Available online: https://www.mdpi.com/2072-4292/9/2/120/pdf (accessed on 1 June 2020). [CrossRef]

60. Arnoldussen, S. The fields that outlived the celts: The use-histories of later prehistoric field systems (celtic fields or raatakkers) in the Netherlands. In Proceedings of the Prehistoric Society; Cambridge University Press: Cambridge, UK, 2018; Volume 84, pp. 303-327.

61. Meylemans, E.; De Bie, M. Revealing extensive protohistoric field systems through high resolution lidar data in the northern part of Belgium. Archäologisches Korresp. 2015, 45, $197-213$. Available online: https://www.researchgate.net/publication/280551305_Revealing_Extensive_Protohistoric_ Field_Systems_through_High_Resolution_LIDAR_Data_in_the_Northern_Part_of_Belgium (accessed on 1 June 2020).

62. Solecki, R. Wykorzystanie lotniczego skanowania laserowego (ALS) w prospekcji dawnych dól uprawnych na przykładzie reliktów z Miłomłyna w powiecie ostródzkim. In Lotnicze Skanowanie Laserowe Jako Narzędzie Archeologii; Gojda, M., Kobyliński, Z., Eds.; Fundacja Res Publica Multiethnica: Warszawa, Poland, 2018; pp. 233-241. Available online: https://archaeologica-hereditas.org/2020/03/08/tom-11-volume-11/ (accessed on 1 June 2020). (In Polish)

63. Dobiegała, M.; Jakubczak, M. Pozostałości Pól Typu Celtic Fields z Miejscowości Michałów-Regiów, Pow. Legionowski, W Świetle Obrazowań Lotniczego Skanowania Laserowego. In Lotnicze Skanowanie Laserowe Jako Narzędzie Archeologii; Gojda, M., Kobyliński, Z., Eds.; Fundacja Res Publica Multiethnica: Warszawa, Poland, 2018; pp. 243-249. Available online: https://archaeologica-hereditas.org/2020/03/08/tom-11-volume-11/ (accessed on 1 June 2020).

64. Stereńczak, K.; Krasnodębski, D.; Zapłata, R.; Kraszewski, B.; Mielcarek, M. Sprawozdanie z Realizacji Zadania Inwentaryzacja Dziedzictwa Kulturowego, w Projekcie pt. Ocena Stanu Różnorodności Biologicznej w Puszczy Biatowieskiej na Podstawie Wybranych Elementów Przyrodniczych i Kulturowych; Forest Research Institute: Sękocin Stary, Poland, 2016. (In Polish)

65. Zapłata, R.; Stereńczak, K. Puszcza Białowieska, LiDAR i dziedzictwo kulturowe-zagadnienia wprowadzajacce. Raport 2016, 11, 239-255. Available online: https:/www.nid.pl/upload/iblock/2e9/ 2e968b90a5e3db3038e08f1c4d5be905.pdf (accessed on 1 June 2020). (In Polish).

66. Zapłata, R.; Stereńczak, K.; Grześkowiak, M.; Wilk, A.; Obidziński, A.; Zawadzki, M.; Stępnik, J.; Kwiatkowska, E.; Kuciewicz, E. Raport Końcowy. Zadanie "Inwentaryzacja Dziedzictwa Kulturowego" na Terenie Polskiej części Puszczy Białowieskiej w Ramach Projektu “Ocena i Monitoring Zmian Stanu Różnorodności Biologicznej W Puszczy Białowieskiej Na Podstawie Wybranych Elementów Przyrodniczych I Kulturowych-Kontynuacja"; Forest Research Institute: Sẹkocin Stary, Poland, 2019. (In Polish)

67. Assessment of the Condition of Biodiversity in the Bialowieza Forest Based on Selected Natural and Cultural Elements" and "Assessment of the Condition of Biodiversity in the Bialowieza Forest Based on Selected Natural and Cultural Elements-Continuation". ("Ocena Stanu Różnorodności Biologicznej w Puszczy Białowieskiej na Podstawie Wybranych Elementów Przyrodniczych i Kulturowych" and "Ocena Stanu Różnorodności Biologicznej w Puszczy Białowieskiej na Podstawie Wybranych Elementów Przyrodniczych i Kulturowych-Kontynuacja"); Forest Research Institute: Sękocin Stary, Poland, 2016. (In Polish)

68. Zapłata, R.; Wilk, A.; Grześkowiak, M.; Obidziński, A.; Zawadzki, M.; Stereńczak, K.; Kuberski, Ł. “Dziedzictwo Kulturowe I Rys Historyczny Polskiej Czẹści Puszczy Białowieskiej", Której Przedmiotem Była "Analiza Wybranych Zasobów Archiwalnych Oraz Wyników Badań Archeologicznych Na Terenie Polskiej Części Puszczy Białowieskiej"; Sprawozdanie końcowe w związku z realizacją umowy nr EO.271.3.5.2019 z dnia 29 marca 2019 r.; Forest Research Institute: Sękocin Stary, Poland, 2019. (In Polish)

69. Ksepko, M.; Porowski, J.; Szubzda, S.; Kolendo, Ł. Raport z Badań Gleboznawczych W Ramach Studiów Archeologicznych W Puszczy Biatowieskiej-Sezon 2017; Bureau for Forest Management and Geodesy: Białystok, Poland, 2018. (In Polish)

70. Goslar, T. Raport z Wykonania Datowań C-14 w Poznańskim Laboratorium Radiowęglowym; Poznan Radiocarbon Laboratory: Poznań, Poland, 2018. (In Polish) 
71. Krapiec, M. Zestawienie Wyników Datowań Radiowęglowych Technika LSC; Laboratorium Datowań Bezwzględnych: Cianowice, Poland, 2019. (In Polish)

72. Van Giffen, A.E. Prehistoric fields in Holland. Antiquity 1928, 2, 85-87.

73. Spek, T.; Waateringe, W.; Kooistra, M.J.; Bakker, L. Formation and land-use history of celtic fields in north-west Europe-an interdisciplinary case study at Zeijen, the Netherlands. Eur. J. Archaeol. 2003, 6, 141-173. [CrossRef]

74. Hesse, R. Detecting Former Field Systems with Airborne LIDAR_An Overview of Current Methods; [poster]; 2012. Available online: https://www.academia.edu/1941481/Detecting_former_field_systems_with_airborne_ LIDAR_an_overview_of_current_methods (accessed on 1 June 2020).

75. Arnoldussen, S.; van der Linden, M. Palaeo-ecological and archaeological analysis of two Dutch Celtic fields (Zeijen-Noordse Veld and Wekerom-Lunteren): Solving the puzzle of local Celtic field bank formation. Veg. Hist. Archaeobot. 2017, 26, 551-570. [CrossRef]

76. Kooistra, M.J.; Maas, G.J. The widespread occurrence of Celtic field systems in the central part of the Netherlands. J. Archaeol. Sci. 2008, 35, 2318-2328. [CrossRef]

77. Nielsen, N.H.; Dalsgaard, K. Dynamics of Celtic fields-A geoarchaeological investigation of Øster Lem Hede, Western Jutland, Denmark. Geoarchaeology 2017, 32, 414-434. [CrossRef]

78. Campana, S. Drones in archaeology. State-of-the-art and future perspectives. Archaeol. Prospect. 2017, 24, 275-296. [CrossRef]

79. Zapłata, R. Koncepcja wsparcia nieinwazyjnego badania zabytków na terenach leśnych w Polsce-System typu Personal Laser Scanning. In Cyfryzacja Naukach Przeszłości Ochr. Zabyt.—Digit. Nieinwazyjne Bad. Dziedzictwa Kult. Situ; Zapłata, R., Ed.; Cardinal Stefan Wyszynski University: Warsaw, Poland, 2015; pp. 57-79. (In Polish)

80. Trier, Ø.; Pilø, L.H. Archaeological mapping of large forested areas, using semi-automatic detection and visual interpretation of high-resolution Lidar data. In Proceedings of the CAA-2014, Paris, France, 26 April 2014; pp. 3-25.

81. Trier, Ø.D.; Pilø, L.H.; Johansen, H.M. Semi-automatic mapping of cultural heritage from airborne laser scanning data. Sémata Cienc. Sociais e Hum. 2015, 27, 159-186.

82. Trier, Ø.D.; Cowley, D.C.; Waldeland, A.U. Using deep neural networks on airborne laser scanning data: Results from a case study of semi-automatic mapping of archaeological topography on Arran, Scotland. Archaeol. Prospect. 2019, 26, 165-175. [CrossRef]

83. Guyot, A.; Hubert-Moy, L.; Lorho, T. Detecting neolithic burial mounds from lidar-derived elevation data using a multi-scale approach and machine learning techniques. Remote Sens. 2018, 10, 225. [CrossRef]

84. Bakuła, K.; Ostrowski, W.; Zapłata, R. Automatyzacja w procesie detekcji obiektów archeologicznych z danych ALS. In Folia Praaehistorica Posnaniensia, XIX; Uniwersytet im. Adama Mickiewicza: Poznań, Poland, 2014; pp. 189-206. (In Polish)

85. Stereńczak, K.; Zapłata, R. Archaeological Heritage in Forested Areas-Challenges, Problems and Solutions. Raport 2018, 13, 117-128. Available online: https:/www.nid.pl/upload/iblock/dcc/ dcc2b53f1d0ec080d36b471ab2823cb2.pdf (accessed on 1 June 2020).

86. Zapłata, R.; Stereńczak, K.; Kraszewski, B. Wielkoobszarowe badania dziedzictwa archeologicznego na terenach leśnych. Kurier Konserwatorski 2018, 15, 47-51.

87. Zapłata, R.; Stereńczak, K. Badania Archeologiczne na Obszarach Leśnych-Aktualne Wyzwania i Możliwości w Dobie Technologii Geoinformacyjnych. In Zastosowanie Geoinformatyki w Leśnictwie; Stereńczak, K., Ed.; Forest Research Institute: Sękocin Stary, Poland, 2020; pp. 383-402. (In Polish)

88. Meylemans, S. The fields that outlived the Celts: The use-histories of later prehistoric field systems (Celtic Fields or Raatakkers) in The Netherlands. In Proceedings of the Prehistoric Society; Cambridge University Press: Cambridge, UK, 2018; Volume 84, pp. 303-327.

89. Opitz, R.S.; Cowley, D.C. Interpreting Archaeological Topography. Airborne Laser Scanning, 3D Data and Ground Observation; Oxbow Books: Oxford, UK, 2013.

90. Bush, M.B.; McMichael, C.H.; Piperno, D.R.; Silman, M.R.; Barlow, J.; Peres, C.A.; Power, M.; Palace, M.W. Anthropogenic influence on Amazonian forests in pre-history: An ecological perspective. J. Biogeogr. 2015, 42, 2277-2288. [CrossRef] 
91. Bush, M.B.; Correa-Metrio, A.; McMichael, C.H.; Sully, S.; Shadik, C.R.; Valencia, B.G.; Guilderson, T.; Steinitz-Kannan, M.; Overpeck, J.T. A 6900-year history of landscape modification by humans in lowland Amazonia. Quat. Sci. Rev. 2016, 141, 52-64. [CrossRef]

92. Fisher, C.T.; Fernández-Diaz, J.C.; Cohen, A.S.; Neil Cruz, O.; Gonzáles, A.M.; Leisz, S.J.; Pezzutti, F.; Shrestha, R.; Carter, W. Identifying ancient settlement patterns through lidar in the mosquitia region of honduras. PLoS ONE 2016, 11, e0159890. [CrossRef]

93. Canuto, M.A.; Estrada-Belli, F.; Garrison, T.G.; Houston, S.D.; Acuña, M.J.; Kováč, M.; Marken, D.; Nondédéo, P.; Auld-Thomas, L.; Castanet, C.; et al. Ancient lowland maya complexity as revealed by airborne laser scanning of northern Guatemala. Science 2018, 80, 361. [CrossRef]

94. Beach, T.; Luzzadder-Beach, S.; Krause, S.; Guderjan, T.; Valdez, F., Jr.; Fernandez-Diaz, J.C.; Eshleman, S.; Doyle, C. Ancient Maya wetland fields revealed under tropical forest canopy from laser scanning and multiproxy evidence. Proc. Natl. Acad. Sci. USA 2019, 116, 21469-21477. [CrossRef]

95. Barbour, T.E.; Sassaman, K.E.; Almeyda Zambrano, A.M.; North Broadbent, E.; Wilkinson Kanaski, B.R. Rare pre-Columbian settlement on the Florida Gulf Coast revealed through high-resolution drone LiDAR. Proc. Natl. Acad. Sci. USA 2019, 116, 23493-23498. [CrossRef]

96. Blicharska, M.; Angelstam, P.; Giessen, L.; Hilszczański, J.; Hermanowicz, E.; Holeksa, J.; Jacobsen, J.B.; Jaroszewicz, B.; Konczal, A.; Konieczny, A.; et al. Between biodiversity conservation and sustainable forest management-A multidisciplinary assessment of the emblematic Białowieża Forest case. Biol. Conserv. 2020, 248, 108614. [CrossRef]

(C) 2020 by the authors. Licensee MDPI, Basel, Switzerland. This article is an open access article distributed under the terms and conditions of the Creative Commons Attribution (CC BY) license (http://creativecommons.org/licenses/by/4.0/). 